\title{
Review \\ Oxytocin and Fear Memory Extinction: Possible Implications for the Therapy of Fear Disorders?
}

\author{
Elisabetta Baldi ${ }^{1}$, Alessia Costa ${ }^{2,+}$, Barbara Rani $^{2,+}{ }^{\circledR}$, Maria Beatrice Passani ${ }^{2}$, Patrizio Blandina ${ }^{3} \mathbb{C D}$, \\ Adele Romano ${ }^{4}$ and Gustavo Provensi ${ }^{3, * \text { (D) }}$ \\ 1 Section of Physiological Sciences, Department of Experimental and Clinical Medicine, University of Florence, \\ 50134 Florence, Italy; e.baldi@unifi.it \\ 2 Section of Clinical Pharmacology and Oncology, Department of Health Sciences (DSS), University of Florence, \\ 50139 Florence, Italy; alessia.costa@unifi.it (A.C.); barbara.rani@unifi.it (B.R.); \\ beatrice.passani@unifi.it (M.B.P.) \\ 3 Section of Pharmacology of Toxicology, Department of Neuroscience, Psychology, Drug Research and Child \\ Health (NEUROFARBA), University of Florence, 50139 Florence, Italy; patrizio.blandina@unifi.it \\ 4 Department of Physiology and Pharmacology 'V. Erspamer', Sapienza University of Rome, 00185 Rome, Italy; \\ adele.romano@uniroma1.it \\ * Correspondence: gustavo.provensi@unifi.it; Tel.: +39-055-2758-296 \\ + Equal contributors.
}

Citation: Baldi, E.; Costa, A.; Rani, B.; Passani, M.B.; Blandina, P.; Romano, A.; Provensi, G. Oxytocin and Fear Memory Extinction: Possible Implications for the Therapy of Fear Disorders? Int. J. Mol. Sci. 2021, 22 10000. https://doi.org/10.3390/ ijms221810000

Academic Editor: Akiyoshi Saitoh

Received: 28 July 2021

Accepted: 10 September 2021

Published: 16 September 2021

Publisher's Note: MDPI stays neutral with regard to jurisdictional claims in published maps and institutional affiliations.

Copyright: (c) 2021 by the authors. Licensee MDPI, Basel, Switzerland. This article is an open access article distributed under the terms and conditions of the Creative Commons Attribution (CC BY) license (https:// creativecommons.org/licenses/by/ $4.0 /)$.

\begin{abstract}
Several psychiatric conditions such as phobias, generalized anxiety, and post-traumatic stress disorder (PTSD) are characterized by pathological fear and anxiety. The main therapeutic approach used in the management of these disorders is exposure-based therapy, which is conceptually based upon fear extinction with the formation of a new safe memory association, allowing the reduction in behavioral conditioned fear responses. Nevertheless, this approach is only partially resolutive, since many patients have difficulty following the demanding and long process, and relapses are frequently observed over time. One strategy to improve the efficacy of the cognitive therapy is the combination with pharmacological agents. Therefore, the identification of compounds able to strengthen the formation and persistence of the inhibitory associations is a key goal. Recently, growing interest has been aroused by the neuropeptide oxytocin (OXT), which has been shown to have anxiolytic effects. Furthermore, OXT receptors and binding sites have been found in the critical brain structures involved in fear extinction. In this review, the recent literature addressing the complex effects of OXT on fear extinction at preclinical and clinical levels is discussed. These studies suggest that the OXT roles in fear behavior are due to its local effects in several brain regions, most notably, distinct amygdaloid regions.
\end{abstract}

Keywords: oxytocin; fear extinction; exposure therapy; amygdala; medial prefrontal cortex; infralimbic cortex; prelimbic cortex; hippocampus

\section{Introduction}

Pathological fear and anxiety are a hallmark of many psychiatric conditions, such as phobias, generalized anxiety, and post-traumatic stress disorder (PTSD). For example, PTSD patients show strong traumatic memories that are retrieved in an intrusive manner, causing re-experiencing of the traumatic event and increased arousal and stress response. The persistence of PTSD can be explained in terms of trauma-induced strengthening of the fear memory or failure to extinguish it [1,2]. These disorders not only seriously undermine the mental health of the affected individuals, but also raise an enormous public health and economic burden on society [3]. For this reason, considerable efforts have been made in the last decades to understand the neurobiological and psychological mechanisms underlying these disorders [4,5]. As most of the mentioned disorders are characterized by pathological fear, it is speculated that they may be, to some extent, fear-circuitry-related disorders [6]. 
Therefore, an enhanced understanding of learned fear is important for the physiological processes underlying these disorders $[1,3,4,7-10]$.

Learned fear can be experimentally studied using the Pavlovian fear conditioning paradigm. It consists of pairing an emotionally neutral stimulus (a discrete cue, such as a tone, a light, or an odor) with an aversive stimulus (the unconditioned stimulus, US, such as a mild electric shock). As a result of this pairing, the initially neutral stimulus (now being a conditioned stimulus, CS) acquires the ability to elicit a typical behavioral conditioned fear response, such as freezing behavior (immobility with the exception of breathing movements) or fear-potentiated startle reflex (an increase in the amplitude of an acoustically elicited startle response) in rodents (often also measured in humans), or skin conductance response in humans [11-14]. In this procedure, the US is also associated with the environment (context) in which the US is presented. Thus, the conditioned fear response will be exhibited in both the CS (cued fear conditioning) and the context (contextual fear conditioning) during the subsequent re-exposure to the CS or context $[12,13,15]$. The association phase between CS and US stimuli constitutes the acquisition phase of fear conditioning, and it is followed by the consolidation phase, during which the memory is stabilized into a consolidated memory (long-term memory) that can be retrieved as needed $[16,17]$. However, when a mnemonic trace is recalled, it enters a labile state and can be more easily modified or even erased [18]. Indeed, prolonged or repeated reexposures to the CS determine a gradual weakening of the memory, a process known as extinction [19-21].

Conditioned fear response extinction represents an important mechanism in the treatment of fear and anxiety disorders; in fact, exposure therapy, an often used treatment, is conceptually based upon fear extinction [22-24]. During exposure therapy, subjects are exposed to stimuli related to the traumatic experience until they suppress their inadequate responses to fear. However, since extinction results in a new mnemonic trace that inhibits the expression of the initial memory, maladaptive defensive behaviors can reappear. This potential for the recovery of maladaptive memory highlights the need to discover more persistent and more robust techniques to decrease maladaptive behaviors [25-27]. In this context, pharmacotherapy can be used to increase the efficacy of exposure therapy. Indeed, some drugs, such as D-cycloserine, 3,4-dihydroxy-L-phenylalanine (L-DOPA), propranolol, and serotonin selective reuptake inhibitors (SSRIs), have been shown to enhance fear extinction in animals, and also in translational studies, as well as in humans $[27,28]$. Recently, it has been reported that administration of acetazolamide, a carbonic anhydrases inhibitor, dose-dependently impaired the consolidation of fear extinction memory of rats trained in contextual fear conditioning, whereas D-phenylalanine, a carbonic anhydrases activator, displayed an opposite action [29]. These findings reveal that the engagement of carbonic anhydrases is essential for providing the brain with the resilience necessary to ensure the consolidation of extinction of emotionally salient events, thus opening the road for novel drug targets.

A series of recent observations are shedding light on the potential involvement of the oxytocinergic system on cognition and, particularly, in the potential use of oxytocin (OXT) as a pharmacological approach to improve exposure-based therapy [30,31]. OXT, a hypothalamic peptide hormone, is well known for its regulatory role of mammalian reproductive processes, such as uterine contraction and milk ejection, but it also plays an important role as a neuropeptide in the brain affecting a wide array of social behaviors, such as pair bonding, social recognition, and maternal care. OXT is involved in the regulation of anxiety and fear, and, interestingly, several neural structures involved in fear extinction express OXT-specific receptors [32-34]. These findings, as well as future challenges and perspectives in the field, will be discussed in this review.

\section{The Central Oxytocinergic System Organization and Potential Therapeutic Applications}

OXT is a nine-amino-acid neuropeptide synthesized in the central nervous system and some peripheral tissues (e.g., myenteric and submucous ganglia along the entire human 
gastrointestinal tract [35], as well as cells and tissues of the reproductive system [36]). However, the central and peripheral release patterns have different temporal dynamics, and it is unclear whether they match and synergize [37].

In the brain of vertebrates, OXT is produced in the magnocellular neurons of the paraventricular (PVN), supraoptic (SON), and accessory (AN) nuclei of the hypothalamus [38]. $\mathrm{PVN}$ and SON axonal projections extend through the median eminence (ME) and innervate the posterior pituitary, where OXT is released into the circulation [39]. Magnocellular neurons also extensively project to various forebrain regions, including the prefrontal cortex, anterior olfactory nucleus, nucleus accumbens, lateral septum, hippocampus, and medial and central amygdala [37,40-43]. Parvocellular hypothalamic and extrahypothalamic PVN projections were found throughout the brain. In particular, they innervate the arcuate nucleus (ARC), the bed nucleus of the stria terminalis (BNST), the ventral tegmental area (VTA), the nucleus of the solitary tract (NTS), the spinal cord, and the hippocampus [44]. Since various subgroups of OXT neurons may innervate distinct brain regions [45], it can be hypothesized that certain stimuli selectively activate neuronal populations with specific intracerebral projections. Indeed, it was recently shown by genetic labeling of OXT neurons activated during fear expression in rats that these "fear-sensitive" OXT cells almost exclusively project to the central nucleus of amygdala, one of the major regions of fear response [46].

OXT is synthesized as a large inactive precursor protein, along with its carrier protein neurophysin I. This precursor is packaged into neurosecretory vesicles and transported axonally to the nerve endings in the neurohypophysis [47]. While it is being transported, the inactive precursor protein is progressively transformed by a variety of post-translational processing steps and hydrolyzed into smaller fragments via a series of enzymes. The last reaction, catalyzed by the peptidylglycine $\alpha$-amidating monooxygenase, releases the biologically active hormone [48]. OXT stored in large dense-core vesicles present at the nerve endings, soma, dendrites, and axonal varicosities is released by calcium-dependent exocytosis. Suitable stimuli for OXT secretion include labor and infant suckling, as well as sexual stimulation, stressors, and gastric distension [49]. Multiple aminopeptidase enzymes are responsible for OXT degradation. The steady state of mature OXT is controlled by oxytocinase enzyme (cystinyl aminopeptidase), which inactivates OXT via hydrolysis [50,51].

OXT exerts its effects, activating biological macromolecules. To date, only one specific OXT receptor (OXTR) is described. The OXTR belongs to the class-A/rhodopsin GPCR family, in which seven transmembrane-spanning helices connected by three extracellular loops and three intracellular loops are clustered in a bundle [52]. OXTRs are functionally coupled to $\mathrm{Gq} / 11$, a class of GTP binding proteins that stimulate, together with $\mathrm{G} \beta \gamma$, the activity of phospholipase $C$. Due to the high structural homology with the neuropeptide vasopressin (AVP), OXT is able activate the AVP receptor subtypes (V1a, V1b, and V2), although with a lower efficiency [53-55]. OXT also readily binds other receptors, such as the transient receptor potential vanilloid-1 receptor (TRPV1) $[56,57]$ or the $\mu$-opioid receptor [58].

Although OXT is best known for its action on the mammary glands and uterus during lactation and childbirth, it is also involved in the neuromodulation of a broad variety of behavioral functions related and unrelated to social behavior. In particular, sexual behavior, maternal care, aggression, pair bonding, and social memory are modulated by brain OXT.

The multiple and known effects of OXT, including its role in controlling stress, anxiety [59-61], and modulating fear responses [46,62,63], suggest OXT as an attractive treatment option in human diseases associated with socio-emotional dysfunctions, such as PTSD, generalized anxiety, phobias, and major depressive disorders. Indeed, intranasal administration of synthetic OXT in healthy subjects reduces anxiety levels and promotes various aspects of human social behaviors $[64,65]$. The same was shown in patients with generalized anxiety, where intranasal administration of OXT produces changes in the activity of some brain areas involved in the regulation of anxiety, such as a decrease in amygdala 
reactivity during the processing of fearful faces [66-68], reduction in the increased activity to sad faces in the MPFC and anterior cingulate cortex [69], and enhancement of amygdala-mPFC and amygdala-anterior cingulate cortex connectivity [70]. Moreover, in PTSD patents, intranasal administration of OXT reduces symptom development, including intrusive re-experiencing [71,72], and enhances functional amygdala-mPFC connectivity, along with inhibitory effects on the amygdala per se [73]. Thus, several studies emphasize OXT as a very interesting add-on therapy for various psychiatric diseases. However, further research is needed to establish OXT as a safe treatment option.

\section{Fear Memory Extinction and Underpinning Network}

Fear extinction occurs when the contingent relationship between the CS and US is compromised following repeated CS presentation without the aversive US. It is characterized by a gradual decrement in the magnitude and frequency of fear responses. It is important to note that extinction does not directly modify the original fear memory. Instead, it leads to the formation of a new inhibitory association CS-no aversive US that competes with the original CS-US memory trace. Thus, extinction does not erase the original association, but rather it implies a new learning that inhibits the original memory from being expressed. In keeping with this view, phenomena such as reinstatement (reappearance of an extinguished fear memory following exposure to unsignaled US after extinction training), spontaneous recovery (reappearance of an extinguished fear memory due to time elapsing after extinction), and renewal (return of an extinguished fear memory in a different context from that in which extinction training took place) after extinction [74] confirm that the original memory is not erased, but remains encoded in the brain without being expressed [75-77]. Extinction is context-dependent and this property is exemplified by the renewal effect. For example, if an extinguished CS is presented in the context in which extinction training occurred, fear is suppressed, but, if the CS is presented in a novel context, fear of the CS returns. Thus, the context in which the CS is presented determines which association (CS-US or CS-no US) is retrieved, thereby determining whether fear is expressed or not. Because extinction is a new learning, it also follows the three classical phases of the mnemonic process: acquisition, consolidation, and retrieval [75-77].

Emerging evidence from both animal (Table 1) and human (Table 2) studies indicates that fear extinction memory is vulnerable to stress [78-80]. Stressors cause impairments in extinction acquisition or retrieval, sometimes in association with increased fear [81]. Moreover, abnormalities in fear extinction are also observed in rodents subjected to stress models, such as "single prolonged stress" (SPS) [82]. In this procedure, animals receive several stressors (restraint, forced swim, and ether anesthesia) in a single session, followed by a 1 week period of rest [82]. These animals exhibit increased anxiety-like behavior in the elevated plus maze, increased contextual fear, and enhanced negative feedback of the HPA axis $[82,83]$. Moreover, they are characterized by reduced expression of OXTR in MPFC, amygdala, and, to a lesser extent, in the hippocampus [84].

Extinction learning requires the plasticity of a scattered network of brain structures to modify the dynamics of distinct neuronal circuits in a way that a previously learned conditioned response is no longer expressed. Important progress has been made in disclosing in rodents the specific roles played by various structures involved in fear extinction. There is much evidence suggesting that the amygdala complex nuclei (including basal (BA), central (CeA, consisting of the lateral (CeL) and medial (CeM) regions), and the intercalated cell masses (ITCs)) are critically involved in acquisition and storage of memory extinction [85-90]. Extinction memory consolidation is mediated by the prelimbic (PL) and infralimbic (IL) areas of the medial prefrontal cortex (mPFC) [91]. The hippocampus has a crucial role in the context-dependent expression of extinction [92,93]. A functional coupling among these areas during fear extinction has been demonstrated in both rodents and humans [94].

Local inactivation of the BA subnucleus with muscimol (a selective agonist of GABAA receptor) blocks extinction acquisition [95]. Moreover, extinction training induces the 
immediate early gene c-Fos expression, a marker of neuronal activation, in the BA [96], which, instead, is compromised in animal models with impaired extinction learning [97]. Interestingly, in this nucleus, two distinct populations of projection neurons, whose activity is oppositely correlated with fear conditioning and extinction, were identified: fear neurons and extinction neurons [95]. The first respond to the CS increasing their firing rate during fear memory retention, whereas the second population is activated during retention of fear memory extinction. Thus, extinction training could induce a switch in the balance of CSevoked activity between these two distinct populations of BA projection neurons [95]. Fear and extinction neurons of the BA exhibit specific reciprocal projections to the mPFC and hippocampus. Specifically, fear neurons are connected with the ventral hippocampus and the PL, whereas extinction neurons are reciprocally connected with IL [98]. These different projections may modulate the balance of BA neuronal activity, allowing expression or not of fear responses. This modulation might be due to an increased GABAergic transmission. Indeed, the gephyrin protein (a structural protein of GABAergic synapse) and mRNAs of other GABAergic markers (such as GABA-synthesizing enzymes) are upregulated after fear extinction training in the basolateral amygdala (BLA) $[99,100]$. It has been proposed that BA neuronal activity is modulated by specific GABAergic interneurons subtypes, specifically cholecystokinin $\left(\mathrm{CCK}^{+}\right)$and the cannabinoid receptor type 1 expressing cells $[99,101,102]$. During extinction, these interneurons would reduce inhibition of extinction neurons which, consequently, increase their responsiveness to the CS [103].

During extinction training, the decrease in CS-elicited fear response parallels with the reduction in CeM neuronal firing [104]. Such effects seem to be related to an inhibitory circuitry, maybe involving BLA and/or CeL, since decreasing the efficacy of intra-amygdala GABAergic transmission impairs extinction memory retrieval [105], whereas enhancing GABAergic transmission facilitates extinction acquisition [106]. The reduced activity of the CeM neurons during extinction could also involve the ITCs. They are clusters of GABAergic neurons located in the external capsule (lateral ITCs, IITCs), lateral to the BLA, and in the intermediate capsule (medial ITCs, mITCs), at the interface of the BLA and CeA. The mITCs are further divided into another two clusters, one located in the proximity of CeL (dorsal mITCs) and another in the proximity of CeM (ventral mITCs). The former project both to CeL and ventral mITCs, whereas the latter project to CeM. Together, these mITC clusters constitute a cellular substrate for gating information flow between the BLA and CeA. They provide feed-forward inhibition to the amygdala: IITCs inhibit the BLA, whereas mITCs inhibit the CeA. These GABAergic neurons are involved in fear extinction. Indeed, selective ablation of mITCs performed after extinction training induces spontaneous recovery of fear responses [107]. On the other hand, extinction increases expression of immediate early genes in mITCs [107-109]. Moreover, extinction leads to a potentiation of excitatory BA extinction neuron inputs to ventral mITCs, which, in turn, increase inhibition of CeM output cells [110].

Finally, the reduced activation of CeM cells by BA neurons appears to also be dependent upon excitation of a specific neuronal population of the CeL. In fact, CeM output neurons are under inhibitory control originating in CeL [111,112]. In this amygdaloid nucleus, two distinct populations of neurons have been found, one exhibiting inhibitory (CeL-OFF) and the other excitatory (CeL-ON) responses to the CS after fear conditioning $[104,113]$. The CeL-OFF neurons express OXTRs $[113,114]$ and exert a tonic inhibitory influence on CeM neurons. For example, release of endogenous OXT in CeL attenuates conditioned freezing [40], probably through the activation of CeL-OFF cells. Moreover, it has been reported that c-Fos expression is increased in these CeL cells in response to contextual fear extinction [115]. This agrees with the proposed function of these neurons in inhibiting the conditioned freezing response [114]. However, further analysis of the activity patterns and recruitment of different CeL neurons is necessary in order to delineate their individual contribution to extinction memory. Overall, these data suggest that the modulation of GABAergic microcircuits within the BLA and CeA is critically involved in the fear extinction. 
Experimental results have shown that $\mathrm{mPFC}$ is able to exert a dual control over fear expression through separate pathways, each with access to separate sets of inputs and outputs [116]. Whereas PL is involved in the production of fear responses and its inactivation reduces expression of contextual and auditory fear conditioning [86,117], IL is a critical site of plasticity for the inhibition of fear responses and, therefore, for the extinction. These findings have been supported by the observation that PL neuronal activity is critical for fear expression and increases in rats that fail to retrieve extinction memory [118], whereas it is reduced by drugs that decrease fear expression, such as propranolol and cannabidiol $[119,120]$. Moreover, PL neurons show increased Fos expression after retrieval [108,121]. It was also speculated that PL modulates fear expression through projections to the BA [122], as PL stimulation excites BA neurons [123]. PL interneurons as well seem to play an essential role in the modulation of fear memory. Reduced activity of PL parvalbumin-positive interneurons disinhibits principal neuron output to the BLA and increases conditioned fear [124]. Contrary to PL, IL is involved in fear extinction. Lesions of this area fail to affect within-session extinction (i.e., the decrement in the fear response measured during extinction training), but impair extinction retrieval. This has been confirmed by studies using single-cell recording, showing that IL neurons respond to signal tones during extinction retrieval, and the magnitude of the response is inversely correlated with behavioral outcome [125]. These findings support a specific role of IL in the retrieval of fear extinction. However, this role is debated. In fact, Do-Monte et al. (2015) have reported that optogenetic silencing of glutamatergic IL neurons during auditory fear extinction retrieval does not abolish retrieval, which, instead, is impaired by silencing IL neurons during extinction acquisition. The authors conclude that the IL activity is not necessary for the retrieval of auditory fear extinction [126]. On the other hand, Laurent and Westbrook (2009) have shown that post-extinction training intra-IL infusion of muscimol impairs extinction of contextual fear [86], whereas infusion of picrotoxin (a GABAergic antagonist) facilitates extinction $[127,128]$, supporting a role for this area of mPFC in extinction consolidation. Finally, during extinction, IL neuron excitability increases [129]. In fact, following extinction, IL neurons respond to intracellular application of current by increasing their bursting. This suggests that these neurons are more responsive to their inputs following extinction [129]. Thus, extinction potentiates inhibitory circuits. Functional neuroimaging studies of healthy humans have reported vmPFC (homologue of the rodent IL) activation during extinction [130-133], and its later recall [130,134]. Skin conductance measures of extinction memory are positively correlated with vmPFC activation $[130,134]$ and vmPFC cortical thickness [135].

Although experimental evidence has shown distinct functions for PL and IL, there is probably some overlapping. Using cell-specific retrograde tracers coupled with optogenetic stimulation, a glutamatergic projection from PL to IL has recently been identified, and its optical stimulation enhances fear extinction [136]. Nevertheless, it is likely that the opposite influence of the IL and PL on fear responses depends, in part, upon the different connections with the amygdala.

The interaction between IL and amygdala is crucial to fear extinction. Specifically, during extinction, the IL controls the signal flow in the BA-CeA circuits, resulting in CeM output neuron inhibition [137]. The IL control of BLA-CeA circuit may be realized through several pathways. IL may activate ventral mITC cells, which, in turn, inhibit the CeM neurons projecting to the effector structures of fear responses [138-140]. In addition, or alternatively, IL inputs may synapse on specific populations of BA interneurons, which induce activation of BA extinction neurons and inhibition of BA fear neurons [103,141]. In turn, extinction neurons may influence CeA activity, acting on either inhibitory ventral mITC neurons or CeL neuronal populations that dampen CeM neurons activity, thus reducing fear responses.

The hippocampus plays a dual role in fear extinction: it modulates both extinction acquisition and context dependence of extinction. These hippocampal roles seem to be controlled by direct and indirect projections to the BLA, PL, and IL [142,143]. 
Pre-extinction muscimol-induced inactivation of the dorsal or ventral hippocampus attenuates or impairs, respectively, fear extinction retention [87,144,145], whereas the same treatment performed immediately after extinction training has no effect on extinction memory $[87,146]$. Likely, these effects are due to the altered communication between the hippocampus and the amygdala.

Pre-extinction retrieval inactivation of the dorsal and ventral hippocampus also abolishes fear renewal [144,147-149]. By contrast, when the same treatment is performed before extinction training, fear renewal occurs [144]. Knapska and Maren (2009) have reported that, during both renewal and extinction memory retrieval, hippocampal c-Fos expression is elevated [108]. Together, these results confirm the role of the hippocampus in the dependence of extinction retrieval on contextual cues. The hippocampus could trigger the context-dependent renewal of conditioned fear responses through its direct projections to the amygdala; both the ventral subiculum and ventral CA1 region of the hippocampus project to the amygdala, although the ventral subiculum projects to BLA and CeM, whereas ventral CA1 projections only terminate in the BA fear neurons [95]. The hippocampus can also affect the amygdala indirectly via its projections to $\mathrm{MPFC}$; the same hippocampal regions that project directly to the amygdala also send projections to the MPFC, both PL and IL [150]. Using cellular imaging c-Fos, Orsini et al. (2011) have examined how the hippocampus and mPFC interact with the BA during fear renewal, showing that BA-projecting neurons within the PL and hippocampus are selectively recruited during the renewal of conditioned fear response. On the contrary, BA-projecting neurons within IL are engaged during extinction recall [142]. This suggests that, during renewal, both the hippocampus and PL actively communicate with the BA.

Extinction-mediating circuits show anatomical and functional similarities in rodents and humans $[27,94]$. Moreover, in humans, vmPFC exerts an inhibitory influence over the amygdala [151]. Furthermore, studies in healthy subjects show that context-dependent vmPFC-hippocampus activation correlates with extinction success $[130,132]$. Thus, vmPFC regulation of amygdalar output and vmPFC-hippocampus connections may be a common circuit underlying fear extinction that may be conserved across species. On the other hand, current data imply dysregulation of hippocampus-prefrontal-amygdala circuits in PTSD, characterized by overactivity of brain regions generating fear and a difficulty engaging circuits normally involved in the inhibition of conditioned fear [79].

Animal and human studies demonstrate that stress induces structural and functional changes in extinction circuits. Extinction-impaired stressed animals exhibit amygdala hyperexcitability, coupled with loss of input sources from hippocampal and prefrontal regions. In the amygdala, specifically in the BLA, chronic stress induces dendritic hypertrophy of principal neurons [152-154], whereas acute stress causes dendritic retraction [155,156]. However, both acute and chronic stress increase BLA spinogenesis [152,156], which is accompanied by increased neuronal excitability and decreased synaptic inhibition [157-159]. On the contrary, stress leads to dendritic retraction in the MPFC and hippocampal neurons [160]. In the $\mathrm{mPFC}$, these alterations have been observed in the IL and are associated with a hypoactivation of this region [160-163]. Maroun and colleagues (2013) have shown stress-induced plasticity changes in the mPFC-BLA pathway and several molecular abnormalities in the mPFC [156]. Moreover, the hippocampus and hippocampus-mPFC connections show functional downregulation to the stress. For instance, postnatal footshock stress reduces extinction-related ERK phosphorylation in the hippocampal CA1 and long-term potentiation in the hippocampus-mPFC pathway $[164,165]$. Moreover, extinction deficits produced by chronic stress are accompanied by a decreased hippocampus-PL transmission [166].

\section{Oxytocin Effects on Fear Memory Extinction}

Growing understanding of the neural circuitry subserving inhibitory learning may offer targets for the development of novel drugs that can be used in combination with behavioral training to strengthen fear extinction, thus contributing to the decrease in patients suf- 
fering. Several techniques (RNA in situ hybridization, autoradiography, transgenic methods combined with viral expression systems and specific OXTR antibodies) [33,167-171] have been used to learn the brain structures critically involved in fear memory processing [80,172-174]. Moreover, OXT has shown anxiolytic properties in animal [175-177] and human studies $[178,179]$. In the following sections we summarize the reports regarding the effects of OXT in the modulation of fear memory extinction, both in animals (see Table 1) and humans (see Table 2).

\subsection{Preclinical Studies}

Data emerging from animal studies show that OXT exerts different effects on fear extinction, depending on the timing and the brain site in which it is administered. The i.c.v. injection of synthetic OXT or a selective OXTR antagonist (OXTR-A) (des Gly$\mathrm{NH} 2, \mathrm{~d}(\mathrm{CH} 2) 5(\mathrm{Tyr}[\mathrm{Me}] 2, \mathrm{Thr} 4) \mathrm{OVT}$ ) before auditory fear conditioning session did not affect either fear memory acquisition or recall [180]. However, the OXT-treated rats (0.1 and $1.0 \mu \mathrm{g}$ ) exhibited reduced freezing responses in comparison to controls during subsequent recalling sessions, indicating a facilitated extinction acquisition. In contrast, OXTR-A injection $(0.75 \mu \mathrm{g})$ caused fear extinction impairment. The OXT-induced facilitatory effect was completely abolished by OXTR-A coadministration. When the compounds were administered before extinction training, contrasting results were found. In rats, OXT treatment at both doses impaired fear extinction, while OXTR-A treatment alone had no effects, but it prevented OXT-induced impairment. In mice, pre-extinction training, OXT injection had an evident dose-dependent effect, since impairment or facilitation of fear extinction were observed following the administration of $0.1 \mu \mathrm{g}$ or $0.5 \mu \mathrm{g}$ OXT [180]. Thus, these results indicate that OXT effects on fear extinction are time- and dose-dependent and may be bidirectional. Recently, OXT biphasic effect has also been shown on social motivation in hamsters [181]. According to the authors, both in males and in females, an inverted U-shaped relationship exists between the duration of social interaction and social reward, mediated by OXT within the VTA [181]. However, there is a sex difference in this relationship, and a particular dose of OXT can induce different patterns of behavior in males and females. For example, injection of $9 \mu \mathrm{L}$ OXT into the VTA decreases social reward in females but increased it in males [181].

Eskandarian et al. (2013) showed that systemic (i.p.) administration of different OXT doses $(1,10,100$, or $1000 \mu \mathrm{g} / \mathrm{Kg})$ immediately after each extinction training session for four consecutive days slowed down both within-session and long-term contextual fear extinction. The rats receiving doses of 10, 100, or $1000 \mu \mathrm{g} / \mathrm{Kg}$ of OXT exhibited higher freezing levels than saline-treated controls during both subsequent four extinction sessions and a retention test performed seven days after the last extinction training session [182]. Using the same protocol, the authors also investigated the effect of i.p. OXT administration on contextual fear extinction in an animal model of stress-induced extinction impairment (SPS procedure). In SPS rats, OXT did not affect contextual fear extinction [182]. In contrast, Wang et al. (2018) showed that intranasal OXT administration $(1 \mu \mathrm{g})$ before a cued fear conditioning extinction test amended the SPS-induced fear extinction impairment [183], suggesting that the augmented OXT levels can enhance fear extinction ability $[73,184]$. The different results in the same animal model may depend on both the different administration time (post-extinction training vs. preconditioning) and the different test (contextual vs. cued fear conditioning). According to the authors, OXT might modulate extinction-processinhibiting glucocorticoid release. Indeed, it has been reported that, when given before extinction, OXT delays fear conditioning extinction in rats in a bimodal manner, depending on the levels of corticosterone released [185]: decreased corticosterone levels block fear extinction [186,187], whereas enhanced corticosterone levels facilitate fear extinction [187].

The time dependence of OXT effects is also highlighted in the neural structures mediating fear extinction, specifically in the BLA, CeA [33,111,188-193], and mPFC [188], which receive oxytocinergic fibers originating from hypothalamic nuclei [40]. OXT-expressing fibers are also found in other memory-related areas, such as the ventral hippocampus [174], 
in which they play a crucial role on social memory consolidation [174]; however, no studies have investigated the hippocampal OXT role in fear extinction.

In the amygdalar complex, changes in OXT signaling can affect fear extinction in various ways, depending on the interested subnucleus.

Intra-BLA synthetic OXT injection $(0.01 \mu \mathrm{g}$, ) after contextual fear memory retrieval (post-extinction training) impaired extinction in rats. On the other hand, the infusion of the selective OXT agonists WAY-267464 (a full agonist with weak affinity for the OXTR) [194], or (Thr4,Gly7)-oxytocin (TGOT, a specific and potent OXTR agonist) at the same time point resulted in different outcomes: TGOT $(7 \mathrm{ng})$ did not affected fear extinction, whereas WAY-267464 $(3 \mu \mathrm{g})$ facilitated fear extinction [188]. When these drugs were given before a fear conditioning session, higher freezing levels were observed in the drug-treated than in the vehicle group during retrieval tests, indicating enhanced contextual fear acquisition and impaired extinction [188]. The different effects of synthetic OXT and Way-267464 might be partly due to their interaction with vasopressin type V1A receptors. Exogenous OXT is a potent agonist of this receptor [194,195], whereas WAY-267464 is a high-affinity antagonist of V1A receptors $[194,195]$. Thus, the OXT at the dose used $(0.01 \mu \mathrm{g})$ could activate vasopressin receptors in addition to the activation of OXTRs. On the other hand, the WAY-267464 effects could be mediated through antagonizing the V1A [188].

In a different study, pre-extinction training administration of synthetic OXT $(0.6,3$, 15 , and $75 \mathrm{ng}$ ) into the BLA facilitated both within-session and long-term contextual fear extinction [189]. However, whereas the effect on within-session extinction seemed to be dose-independent, that on long-term extinction was dose-dependent. Rats trained under higher doses of OXT $(3,15$, and 75 ng) exhibited lower freezing levels than rats trained under the lowest dose ( $0.6 \mathrm{ng})$ during the retention test [189]. OXT injection immediately post-extinction training into the BLA did not alter animals' behavior, suggesting that OXT-related effects were not due to a potentiation of the extinction-consolidation phase. The administration of OXTR-A (OXTR antagonist, $15 \mathrm{ng}$ ) directly into the BLA had no effect on conditioned freezing response, but it fully prevented the facilitatory effect when co-administered with OXT [189]. Although the expression of OXTRs on BLA neurons has not been demonstrated [95], it can be speculated that the pro-extinction OXT effects in BLA might be due to the neuropeptide action on BLA extinction and fear neurons activating the former and inhibiting the latter. OXT might act directly on the principal neurons or act on specific classes of BLA interneurons, thus reducing activation of intrinsic amygdaloid pathways by CS $[107,196]$. Future studies are required to clarify the specific OXT actions on this circuit.

The OXT effects on fear extinction were also studied in rodent models of impaired extinction. For example, the murine strain 129S1SvImJ (S1) shows extinction deficits and several abnormalities in the amygdala and $\mathrm{mPFC}$, such as BLA, CeA, and IL hypoactivation and CeM hyperactivation [197-199]. Pre-extinction training intra-BLA OXT (0.01 $\mu \mathrm{g})$ injection in these mice did not affect either extinction acquisition or retrieval [191]. On the contrary, the same OXT dose applied into the CeA before extinction training facilitated extinction, possibly by promoting the consolidation process. Instead, a $1.0 \mu \mathrm{g}$ dose of OXT given into the CeA led to an impairment of extinction retrieval, further demonstrating that neuropeptide effects are dose-dependent. These results suggest that the proextinction effects of OXT are specific to the CeA within the amygdala and confirm the observation of previous studies. Using autoradiography of rat brain sections, Huber et al. (2005) observed that OXTRs are specifically located in the CeL. Subsequently, recording spontaneous spiking activity in acute slices of CeA and manipulating with different OXTR agonists and antagonists, they described two neuronal populations: one was excited by OXT receptor activation, whereas another was inhibited by OXT activation. Finally, they found that TGOT application activated a specific GABAergic neuronal population in the $\mathrm{CeL}$ that projects to the CeM, enhancing the inhibitory postsynaptic currents. This effect was abolished by application of OXTR antagonists. Thus, OXT enhances excitability of neuronal populations in the CeL, which leads to increased release of GABA in the CeM [111]. 
These results have been confirmed by further studies, which have shown that OXT administration in the CeA reduces expression of fear in rodents, facilitating fear extinction $[40,190]$. Female and male rats received TGOT (7 $\mathrm{ng})$ injection into the CeA before the contextual fear retention test. TGOT-treated rats exhibited reduced freezing levels to the context, indicating facilitated extinction [190]. Moreover, in the same study, in vitro electrophysiological recordings showed that TGOT excited CeL interneurons firing and enhanced inhibitory synaptic transmission in CeM neurons projecting to the periaqueductal gray (PAG), the effector structure of freezing behavior. Thus, according to the authors, TGOT accelerated fear extinction via OXTR-expressing CeL neurons, which inhibited the CeM neurons projecting to the PAG [190]. These results have been confirmed by Knobloch et al. (2012) using an optogenetic approach. Optogenetic stimulation of endogenous OXT release into the CeA before contextual fear retention test induced freezing response reduction in female rats. This effect was abolished by OXTR antagonist $(\mathrm{d}(\mathrm{CH} 2) 5$ $\operatorname{Tyr}(\mathrm{Me})-(\mathrm{Orn} 8)$-vasotocin, $1 \mu \mathrm{M}$ ) injection into the CeA. In vitro optogenetic stimulation increased both action potential frequency of CeL neurons and inhibitory postsynaptic current frequency in CeM neurons. Both effects were blocked by OXTR antagonist administration [40]. Overall, these studies confirm that OXT activates GABAergic CeL neurons, which, in turn, increase GABArgic inhibition in PAG-projecting CeM output neurons, attenuating contextual freezing responses and facilitating fear extinction $[40,190]$. Data in agreement with these studies have been reported by Hasan et al. (2019). Using a novel method based on virus-delivered genetic-activity-induced tagging of cell ensembles (vGATE), the authors labeled fear-activated OXT-expressing neurons in the female rat hypothalamus. They observed that PVN and SON OXT neurons were activated during contextual fear conditioning, and a fraction of these neurons was reactivated after re-exposure to the same context on the next day. However, when the same animals were exposed to a different context, a significantly higher number of OXT neurons was activated, indicating that a new OXT neuron population was recruited [46]. These fear-activated OXT neurons projected specifically to the CeL. Their optogenetic activation reduced contextual fear, whereas their silencing impaired context-specific fear extinction [46]. Thus, OXT plays a critical role in the CeA, attenuating contextual fear memory and facilitating fear extinction [40,190]. Therefore, OXT in the amygdala seems to act mainly in the CeA influencing CeL-OFF cells. It has been reported that many CeL-OFF neurons (expressing protein kinase $\mathrm{C} \delta\left(\mathrm{PKC} \delta^{+}\right)$) express OXTRs [114]. Thus, the enhanced OXT release in the CeL by oxytocinergic fibers originating in the hypothalamic nuclei might activate CeL-OFF neurons, which, in turn, would inhibit the CeM output neurons suppressing conditioned fear responses.

Later studies have reported results confirming the region-dependent function of OXT in the amygdala. Synthetic OXT (10 ng) or WAY-267464 (3 $\mu \mathrm{g})$ applied to the CeA after the first session of contextual fear retention did not induce any effect on freezing response extinction in male rats [188]. Instead, intra-CeA WAY-267464 or TGOT (7 ng) administration before fear acquisition facilitated the subsequent extinction, whereas synthetic OXT had no effects [188]. In another study [189], injection of several doses of OXT (0.6, 3, 15, and $75 \mathrm{ng})$ into the CeA before the contextual fear extinction training impaired both within-session and long-term extinction. These effects were dose-independent, as the groups treated with different doses of OXT exhibited similar levels of freezing. The coadministration of OXT (15 ng) and an OXT antagonist (desGly-NH2-d(CH2)5(D-Tyr2,Thr4)OVT, OTA, 75 ng) in CeA blocked OXT effects, whereas infusion of OXTA alone facilitated fear extinction. On the contrary, pre-extinction training infusion of TGOT into the CeA impaired within-session but not long-term extinction [189]. The different results by various studies might be due to sex differences (female vs. male rats) and to the different doses used, as OXT effects on fear extinction are, at least in part, sex-specific and dose-dependent [180]. In addition, the drug dose used might also act on vasopressin receptors (V1A), for which they show different affinity and whose activation has opposite effects [31,111]. Moreover, there are multiple mechanisms by which the OXTRs can be transcriptionally induced and differentially involved in several types of behaviors. For instance, in the ventromedial nucleus of the 
hypothalamus (VMH), OXTR induction is estrogen-dependent and requires protein kinase $\mathrm{C}$ activation, whereas, in the CeA OXTR expression is controlled by dopamine through activation of protein kinase A (PKA) [175]. OXT infused in VMH promotes female sexual behavior but has no effect on anxiety; in contrast, OXT administration in CeA has anxiolytic effects but does not influence female sexual behavior [175]. It may speculate that OXT effects on fear extinction in the CeA are PKA-dependent and activated by dopamine D1 receptors. However, there is no experimental evidence.

The partly controversial findings imply a critical role for OXT signaling in amygdalabased regulation of fear learning. OXT may inhibit but also enhance context and cued fear expression and extinction depending on-the site of action within amygdaloid subregions, - the dose used, - the precise time point of application of OXT or its agonists, and - the sex studied. Thus, increasing local OXT neurotransmission during traumatic events may prevent the formation of fear memories, whereas, in contrast, OXT treatment before fear extinction training may delay and impair cued or context fear extinction.

As described above, the IL subregion of the MPFC is a critical site in fear extinction regulation. Concerning OXT activity in this area, a recent study showed that synthetic OXT (10 ng) or WAY-267464 (3 ng) infusions after the first session of fear retention test in male rats facilitated contextual fear extinction. Indeed, OXT- and WAY-treated rats exhibited lower levels of freezing than controls; however, both experimental groups were not different from each other [188]. Similar results have been obtained using TGOT $(7 \mathrm{ng})$ administered into the IL before the second retention test. In contrast, injection of an OXTR antagonist into the same cerebral site had no effect [200]. The same authors have reported that intra-IL TGOT infusion in adolescent rats had no effect on fear extinction, suggesting that OXT effects on fear extinction are age-dependent. This likely is due to the incomplete development of the neuronal circuits in the central nervous system, especially in mPFC [201]. Moreover, in juvenile animals extinction seems to be based on mechanisms and circuits which display distinct features from the adult [202].

It has been speculated that extinction facilitation induced by OXT in the IL could be due to plasticity enhancement and facilitation of glutamatergic synapses in this area. In fact, potentiation of synaptic transmission in the IL underlies fear extinction consolidation [203-206] and intra-IL OXT administration is associated with long-lasting potentiation of excitatory postsynaptic currents in IL brain slices [207]. However, studies describing the mechanisms of OXT on synaptic plasticity in cerebral sites involved in fear extinction are still scarce. At the circuit level, the increased release of endogenous OXT from hypothalamic nuclei may activate different inhibitory neuronal populations expressing OXTRs in the cerebral sites underlying fear extinction that collaborate together to diminish conditioned fear responses during retrieval and allow for fear extinction.

OXT mechanisms of action within the neural circuits of fear extinction remain unclear. Experimental evidence suggests that this neuropeptide may interact with several neurotransmitter systems. In particular, the anxiolytic effects of OXT might be mediated via the potentiation of GABAergic transmission. GABA is the main inhibitory neurotransmitter in the brain $[208,209]$. Its inhibitory effects are mediated by ionotropic GABA-A or metabotropic GABA-B receptors. GABA-A receptors are fast-acting ligand-gated chloride channels. Their activation induces an enhanced chloride conductance across the cell membrane, which reduces the neuron ability to raise an action potential and leads to phasic inhibition of the neuron [210]. Moreover, low concentrations of GABA in the extracellular space can persistently activate extrasynaptic GABA-A receptors and generate a tonic inhibition, rendering the neuron less responsive to excitatory stimuli [211]. GABA-B receptors are coupled via G-proteins to either calcium or potassium channels and produce slow and prolonged inhibitory responses [212].

There are only a few studies on the interactions between central OXT and GABA systems. Central OXT acts directly on extrasynaptic GABA-A receptors [213]. Furthermore, OXTRs are located on GABAergic neurons and interneurons in several brain areas, including the amygdala $[40,111]$ and the mPFC [214]. Experimental results support the 
hypothesis that OXT exerts a direct excitatory effect on GABAergic neurons in the CeL, resulting in the inhibition of target neurons in the CeM, and may thereby enhance fear responses extinction. Recent work has demonstrated that OXT in the mPFC of male rats attenuates anxiety-related behavior engaging GABAergic neurons, which modulate neuronal activation in the BLA and CeA [215].

Interestingly, it has been shown that OXT synergizes with benzodiazepines to inhibit $\mathrm{CeM}$ activity. The benzodiazepines (such as diazepam and lorazepam) are commonly used for anxiety disorder treatment. However, they show several side effects, including dependence and withdrawal symptoms after long-term use [216]. These drugs bind to GABA-A receptors and enhance their functions. Viviani et al. (2010) have found that the coapplication of OXT and diazepam facilitates the inhibitory effects of diazepam in rats of either sex. Thus, stronger anxiolysis can be obtained by combining the two substances. OXT has a different site of action than diazepam. In fact, whereas OXT acts directly on CeL (GABAergic) neurons through OXTRs, diazepam inhibits CeM neurons through GABA-A receptors. This makes possible the therapeutic action of OXT in those circumstances in which chronic use of benzodiazepines leads to tolerance [217]. Similar results have been reported in humans. Using functional ultra-high-field imaging in healthy males, Kreuder et al. (2020) compared the effects of OXT and lorazepam on fear-related activity and connectivity in distinct nuclei of the human amygdala. They found that both OXT and lorazepam reduce responses to fearful faces relative to neutral faces activating GABAergic transmission within the CeA [218]. In addition, OXT significantly increased the functional connectivity between the BLA and the CeA, and between the amygdala and the PFC during processing of fearful faces.

\subsection{Human Studies}

Substantial evidence from animal studies has highlighted OXT implication in extinction learning in humans. For the purpose of corroborating the commonly used exposure therapy, efforts are focused on pharmacological augmentation of extinction learning. Relatively few clinical studies have been conducted on the role of OXT as a pharmacological adjunct for exposure-based therapy (see Table 2).

As previously described for animal studies, OXT effects on fear learning is time dependent. Indeed, in humans also, different outcomes were reached with the OXT administration in different phases of the extinction process. Acheson et al. (2013) studied 44 healthy participants administered with intranasal (IN) OXT or placebo before the conditioned fear extinction training. The authors used a fear protocol consisting of a twographical presentation (CS): one (CS+) is paired with a $0.5 \mathrm{~s}$ electric shock (US), whereas the CS - is never followed by a shock. After this initial acquisition and the drug administration in the extinction phase, the subjects were presented with the graphical CS+ not paired with a shock, or CS-, and the startle response was measured. The authors observed an inhibition of fear extinction (startle response, measured as the difference between startle magnitude in response to CS+ or CS- and the startle response to noise probe alone) in the OXT condition at the beginning of the extinction training, while a similar fear response was shown in the mid-fear-extinction training between OXT and placebo. Instead, when tested on the late extinction phase ( $24 \mathrm{hr}$ after treatment), the OXT administered group displayed a greater extinction recall relative to placebo, supporting a facilitative effect of OXT treatment in enhancing consolidation of fear extinction training. The study suggests, overall, a potential effect of OXT in fear extinction recall facilitation [184]. The OXT dual effect on extinction, an initial increase in fear response versus an enhanced extinction learning at the end of the extinction training, was also indicated by a randomized doubleblind placebo-controlled study of 62 healthy participants [73]. Specifically, subjects were exposed to a Pavlovian fear conditioning and extinction paradigm with concomitant functional magnetic resonance imaging (fMRI). During the conditioning, a brief electrical shock with an intensity perceived as "highly annoying but not painful" was applied to one hand as US, while the CS was chosen as a social or non-social neutral face representation. 
Throughout the procedure, the skin conductance responses of the hand were sampled with fMRI scan and subtracted to the baseline conductance value. Repeated measures ANOVA analysis permitted discrimination between OXT vs. placebo effect in response to faces representation. OXT or placebo administration was given at the end of the conditioning and before the extinction, which took place on the same day. As previously shown by Acheson et al. (2013), the latter study also showed an initial increase, followed by a late decrease in fear extinction learning in the OXT group. Despite the same outcomes, the two studies differ for the timing of the extinction process. In the former study, the extinction training was comprehensive of the different phases of Pavlovian memory, including the conditioning, reconsolidation, extinction, and recall, as the evaluation was done over $24 \mathrm{~h}$ after the OXT administration, being inclusive of the after-conditioning reconsolidation and after-extinction recall. Instead, in the latter study, the procedure was conducted on the same day, excluding the reconsolidation and recall phases, precluding the deduction of OXT effect on the extinction alone [73]. Both neuroimaging studies have also demonstrated a decrease in amygdala reactivity after OXT treatment, in agreement with the growing literature showing the reduction in amygdala activity throughout extinction following social and non-social aversive stimuli [65]. However, more intriguing is the finding of Eckstein et al. (2015) showing the implication of the dorsal region of the mid-medial PFC following OXT treatment. The authors showed an activation of mid-medial PFC only during initial fear extinction training, but not during the late phase of extinction [73], suggesting an increase in the physiological response at the beginning of the learning phase where the behavioral outcome is an increased fear expression.

$\mathrm{Hu}$ et al. (2019) showed in a double-blind placebo-controlled study on 61 healthy subjects a facilitatory effect of OXT in the extinction process, tested in the extinction computer task. Specifically, the skin conductance responsivity was measured in a 3-day experiment. The participants, after the conditioning on day 1 during which the presentation of an image was paired with a mild shock on the wrist (CS+), whereas another picture was not paired with a shock (CS-), were administered OXT or placebo and randomly assigned to the retrieval or non-retrieval group. On day 3, the participants were tested for extinction (image presentation without shock) and reinstatement (unsignaled mild shock without picture presentation). Despite an initial equivalent stimulus discrimination, the OXT retrieval group showed a reduction in stimulus discrimination on the late extinction phase, suggesting that OXT interacts with postretrieval processes rather that blocking consolidation to facilitate extinction [219].

In an attempt to investigate the OXT-induced modulation of brain regions known to be involved in the fear extinction process, Kirsch and colleagues (2005) demonstrated a potent reduction in the amygdala reactivity and amygdalar output pathways to midbrain after IN OXT administration. In this double-blind study, 15 healthy male participants were administered with OXT or placebo intranasally and then subjected to an fMRI and functional connectivity concomitant with the presentation of fearful socially and non-socially relevant stimuli. Each participant was asked to match the previous social stimulus with the paired non-social stimulus. Compared to placebo, OXT administration depressed amygdala activation, in particular, when the social stimulus was presented separately. Moreover, functional connectivity analysis showed a reduced amygdala-upper brainstem $/ \mathrm{midbrain}$ connectivity during OXT condition, suggesting an OXT combined effect on amygdala and midbrain regions mediating behavioral and autonomic fear responses [65].

Despite the findings reported for healthy subjects in clinical studies, a greater complexity of the OXT effect on extinction is reported when evaluated as a pharmacological adjunct for exposure therapy. As was shown in a double-blind study inclusive of 25 patients with social anxiety disorders (SAD), the OXT administration in combination with exposure therapy improved self-appraisal of speech performance across treatment, but these effects did not improve overall symptoms compared to placebo, as evaluated by self-report measures of SAD symptoms (i.e., social phobia fear and avoidance symptoms, etc.) [220], suggesting an OXT effect specifically on the exposure target rather than causing a generalized reduc- 
tion in social anxiety symptoms. The OXT efficacy as an enhancer of exposure therapy was also tested in 23 arachnophobic subjects [184]. In the study, OXT delivery before exposure therapy did not significantly affect behavioral measures of fear and tended to decrease therapeutic alliance and response to treatment at follow-up [184]. On the other hand, clinical trials involving PTSD patients have shown a positive effect of OXT treatment when associated to exposure therapy. Koch et al. (2016) reported in an fMRI analysis that OXT has the potential to diminish anxiety and fear expression of the amygdala in PTSD, as tested in 37 PTSD patients versus 40 healthy subjects treated with OXT or placebo. In the clinical trials, a BLA and CeM functional connectivity with salience processing areas was also shown. Under placebo, PTSD patients showed a reduced connectivity between $\mathrm{CeM}$ and vmPFC, and between BLA and bilateral dorsal anterior cingulate cortex (dACC). The former was reinstated, while the latter was dampened after OXT administration, suggesting that the OXT potential to modulate anxiety and fear expression of the amygdala in PTSD could be partially due to increased control of the vmPFC over the CeM or via decreased salience processing of the AACC and BLA [68]. The same outcome was reported by Flanagan et al. (2018) employing a randomized, placebo-controlled double-blind study where 17 PTSD patients were treated with intra-nasal OXT before each session of exposure therapy. The patients in the OXT group showed lower PTSD- and depression-associated symptoms during the exposure therapy and a higher working alliance score [221]. An fMRI study in agreement with the previous reports suggested a positive effect of OXT administration early post-trauma in PTSD patients. In this study, a single dose of OXT attenuated amygdala-ventromedial and ventrolateral PFC functional connectivity, whereas a repeated OXT dosage reduced PTSD symptom development in recently trauma-exposed emergency department patients with high acute PTSD symptoms [72], showing potential administration frequency-dependent effects of OXT.

It is remarkable that data regarding the side effects (incidence or severity) were not reported in the above studies.

Table 1. Summary of preclinical studies in rodents assessing the OXT system manipulation effects on fear extinction.

\begin{tabular}{|c|c|c|c|c|c|}
\hline Animals & $\begin{array}{l}\text { Route or Site of } \\
\text { Administration }\end{array}$ & Drug Administered & $\begin{array}{c}\text { Time of } \\
\text { Administration }\end{array}$ & $\begin{array}{l}\text { Effect on Fear } \\
\text { Extinction }\end{array}$ & Reference \\
\hline Male Wistar rats & i.c.v. & OXT $(1.0 \mu \mathrm{g} / 5 \mu \mathrm{L})$ & Preconditioning AFC & + & [180] \\
\hline Male Wistar rats & i.c.v. & OXTR-A $(0.75 \mu \mathrm{g} / 5 \mu \mathrm{L})$ & Preconditioning AFC & - & [180] \\
\hline Male Wistar rats & i.c.v. & OXT $(0.1$ or $1.0 \mu \mathrm{g} / 5 \mu \mathrm{L})$ & Pre-extinction AFC & -Both doses & [180] \\
\hline Male Wistar rats & i.c.v. & OXTR-A $(0.75 \mu \mathrm{g} / 5 \mu \mathrm{L})$ & Pre-extinction AFC & No effect & [180] \\
\hline Male CB1 mice & i.c.v. & OXT $(0.1$ or $0.5 \mu \mathrm{g} / 2 \mu \mathrm{L})$ & Pre-extinction AFC & $\begin{array}{l}-(0.1 \mu \mathrm{g} / 2 \mu \mathrm{L}) \\
+(0.5 \mu \mathrm{g} / 2 \mu \mathrm{L})\end{array}$ & [180] \\
\hline Male Wistar rats & i.p. & $\begin{array}{l}\text { OXT }(1,10,100, \text { or } 1000 \\
\mu \mathrm{g} / \mathrm{Kg}) \text { (multiple injections) }\end{array}$ & Post-extinction CFC & $\begin{array}{c}-(10,100 \text { or } 1000 \\
\mu \mathrm{g} / \mathrm{Kg})\end{array}$ & [182] \\
\hline $\begin{array}{l}\text { Male Wistar rats } \\
\text { subjected to SPS } \\
\text { procedure }\end{array}$ & i.p. & $\begin{array}{l}\text { OXT }(1,10,100, \text { or } 1000 \\
\mu \mathrm{g} / \mathrm{Kg}) \text { (multiple injections) }\end{array}$ & Postextinction CFC & No effect & [182] \\
\hline $\begin{array}{l}\text { Male Sprague-Dawley } \\
\text { rats }\end{array}$ & IN & OXT $(1 \mu \mathrm{g} / \mu \mathrm{L})$ & $\begin{array}{l}\text { Pre-extinction test of } \\
\text { CDFC }\end{array}$ & + & [183] \\
\hline $\begin{array}{l}\text { Male Sprague-Dawley } \\
\text { rats subjected to SPS } \\
\text { procedure }\end{array}$ & IN & OXT $(1 \mu \mathrm{g} / \mu \mathrm{L})$ & $\begin{array}{l}\text { Pre-extinction test of } \\
\text { CDFC }\end{array}$ & + & [183] \\
\hline $\begin{array}{l}\text { Male Sprague-Dawley } \\
\text { rats }\end{array}$ & BLA & OXT $(0.01 \mu \mathrm{g} / 0.5 \mu \mathrm{L})$ & Postretrieval CFC & - & [188] \\
\hline $\begin{array}{l}\text { Male Sprague-Dawley } \\
\text { rats }\end{array}$ & BLA & WAY-267464 (3 $\mu \mathrm{g} / 0.5 \mu \mathrm{L})$ & Postretrieval CFC & + & [188] \\
\hline
\end{tabular}


Table 1. Cont.

\begin{tabular}{|c|c|c|c|c|c|}
\hline Animals & $\begin{array}{l}\text { Route or Site of } \\
\text { Administration }\end{array}$ & Drug Administered & $\begin{array}{c}\text { Time of } \\
\text { Administration }\end{array}$ & $\begin{array}{l}\text { Effect on Fear } \\
\text { Extinction }\end{array}$ & Reference \\
\hline $\begin{array}{l}\text { Male Sprague-Dawley } \\
\text { rats }\end{array}$ & BLA & TGOT $(3.5$ or $7 \mathrm{ng} / 0.5 \mu \mathrm{L})$ & Postretrieval CFC & No effect both doses & {$[188,201]$} \\
\hline $\begin{array}{l}\text { Male Sprague-Dawley } \\
\text { rats }\end{array}$ & BLA & OXT $(0.01 \mu g / 0.5 \mu \mathrm{L})$ & Preacquisition CFC & - & {$[188]$} \\
\hline $\begin{array}{l}\text { Male Sprague-Dawley } \\
\text { rats }\end{array}$ & BLA & WAY-267464 $(3 \mu \mathrm{g} / 0.5 \mu \mathrm{L})$ & Preacquisition CFC & - & {$[188]$} \\
\hline $\begin{array}{l}\text { Male Sprague-Dawley } \\
\text { rats }\end{array}$ & BLA & TGOT (7 ng/0.5 $\mu \mathrm{L})$ & Preacquisition CFC & - & {$[188]$} \\
\hline Male Wistar rats & BLA & OXT (75 ng/0.3 $\mu \mathrm{L})$ & Preacquisition CFC & + & [189] \\
\hline Male Wistar rats & BLA & $\begin{array}{l}\text { OXT }(0.6,3,15 \text {, or } 75 \mathrm{ng} / 0.3 \\
\mu \mathrm{L})\end{array}$ & $\begin{array}{l}\text { Pre-extinction CFC } \\
\text { (single injection) }\end{array}$ & $\begin{array}{l}\text { +within-session } \\
\text { extinction (all doses) } \\
\text { +LT extinction } \\
\text { (higher doses) }\end{array}$ & [189] \\
\hline Male Wistar rats & BLA & OXTA (3 ng/0.3 $\mu \mathrm{L})$ & $\begin{array}{l}\text { Pre-extinction CFC } \\
\text { (single injection) }\end{array}$ & No effect & [189] \\
\hline Male Wistar rats & BLA & $\begin{array}{l}\text { OXT }(3 n g / 0.3 \mu \mathrm{L})+\text { OXTA } \\
(15 n g / 0.3 \mu \mathrm{L})\end{array}$ & $\begin{array}{l}\text { Pre-extinction CFC } \\
\text { (single injection) }\end{array}$ & No effect & [189] \\
\hline Male Wistar rats & BLA & OXT (3 ng/0.3 $\mu \mathrm{L})$ & $\begin{array}{l}\text { Postextinction CFC } \\
\text { (single injection) }\end{array}$ & No effect & [189] \\
\hline $\begin{array}{l}\text { Male juvenile } \\
\text { Sprague-Dawley rats } \\
\text { (P27) }\end{array}$ & BLA & TGOT (3.5 or $7 \mathrm{ng} / 0.5 \mu \mathrm{L})$ & Postretrieval CFC & -Both doses & {$[201]$} \\
\hline $\begin{array}{l}\text { Male juvenile } \\
\text { Sprague-Dawley rats } \\
\text { (P27) }\end{array}$ & BLA & TGOT (7 ng/0.5 $\mu \mathrm{L})$ & Preacquisition CFC & No effect & {$[201]$} \\
\hline Male 129SvImJ mice & BLA & OXT $(0.001 \mu \mathrm{g} /$ side $)$ & $\begin{array}{l}\text { Pre-extinction AFC } \\
\text { (single injection) }\end{array}$ & No effect & {$[191]$} \\
\hline Male $129 S v I m J$ mice & $\mathrm{CeA}$ & OXT (0.01 or $1.0 \mu \mathrm{g} /$ side $)$ & $\begin{array}{l}\text { Pre-extinction AFC } \\
\text { (single injection) }\end{array}$ & $\begin{array}{c}+(0.01 \text { or } 1.0 \mu \mathrm{g} / \mathrm{side}) \\
-(1.0 \mu \mathrm{g} / \mathrm{side})\end{array}$ & {$[191]$} \\
\hline $\begin{array}{l}\text { Male Sprague-Dawley } \\
\text { rats }\end{array}$ & $\mathrm{CeA}$ & TGOT (7ng/0.5 $\mu \mathrm{L})$ & Pre-retention CFC test & + & {$[190]$} \\
\hline Female Wistar rats & $\mathrm{CeA}$ & $\begin{array}{l}\text { Endogenous OXT (released } \\
\text { following optogenetic } \\
\text { stimulation) }\end{array}$ & Pre-retention CFC test & + & {$[40]$} \\
\hline Female Wistar rats & $\mathrm{CeA}$ & OXTA $(21 \mathrm{ng} / 0.5 \mu \mathrm{L})$ & Pre-retention CFC test & No effect & {$[40]$} \\
\hline Female Wistar rats & $\mathrm{CeA}$ & OXTA + endogenous OXT & Pre-retention CFC test & No effect & {$[40]$} \\
\hline $\begin{array}{l}\text { Male Sprague-Dawley } \\
\text { rats }\end{array}$ & $\mathrm{CeA}$ & OXT $(0.01 \mu \mathrm{g} / 0.5 \mu \mathrm{L})$ & Preacquisition CFC & No effect & {$[188]$} \\
\hline $\begin{array}{l}\text { Male Sprague-Dawley } \\
\text { rats }\end{array}$ & $\mathrm{CeA}$ & WAY-267464 (3 $\mu \mathrm{g} / 0.5 \mu \mathrm{L})$ & Preacquisition CFC & + & {$[188]$} \\
\hline $\begin{array}{l}\text { Male Sprague-Dawley } \\
\text { rats }\end{array}$ & $\mathrm{CeA}$ & TGOT (7 ng/0.5 $\mu \mathrm{L})$ & Preacquisition CFC & + & {$[188,201]$} \\
\hline $\begin{array}{l}\text { Male Sprague-Dawley } \\
\text { rats }\end{array}$ & $\mathrm{CeA}$ & OXT $(0.01 \mu \mathrm{g} / 0.5 \mu \mathrm{L})$ & Postretrieval CFC & No effect & {$[188]$} \\
\hline $\begin{array}{l}\text { Male Sprague-Dawley } \\
\text { rats }\end{array}$ & $\mathrm{CeA}$ & WAY-267464 (3 $\mu \mathrm{g} / 0.5 \mu \mathrm{L})$ & Postretrieval CFC & No effect & {$[188]$} \\
\hline Male Wistar rats & $\mathrm{CeA}$ & OXT (75 ng/0.3 $\mu \mathrm{L})$ & Preacquisition CFC & + & [189] \\
\hline Male Wistar rats & $\mathrm{CeA}$ & $\begin{array}{l}\text { OXT }(0.6,3,15 \text {, or } 75 \mathrm{ng} / 0.3 \\
\mu \mathrm{L})\end{array}$ & Pre-extinction CFC & $\begin{array}{l}\text {-Both within-session } \\
\text { and LT extinction (all } \\
\text { doses) }\end{array}$ & [189] \\
\hline Male Wistar rats & $\mathrm{CeA}$ & TGOT (7 ng/0.3 $\mu \mathrm{L})$ & Pre-extinction CFC & $\begin{array}{l}\text {-Within-session } \\
\text { extinction } \\
\text { No effect on LT } \\
\text { extinction }\end{array}$ & [189] \\
\hline
\end{tabular}


Table 1. Cont.

\begin{tabular}{|c|c|c|c|c|c|}
\hline Animals & $\begin{array}{l}\text { Route or Site of } \\
\text { Administration }\end{array}$ & Drug Administered & $\begin{array}{c}\text { Time of } \\
\text { Administration }\end{array}$ & $\begin{array}{l}\text { Effect on Fear } \\
\text { Extinction }\end{array}$ & Reference \\
\hline Male Wistar rats & $\mathrm{CeA}$ & OXTA $(15 \mathrm{ng} / 0.3 \mu \mathrm{L})$ & Pre-extinction CFC & $\begin{array}{l}+ \text { Both within-session } \\
\text { and LT extinction }\end{array}$ & [189] \\
\hline Male Wistar rats & $\mathrm{CeA}$ & OXT (15 ng) + OXTA (75 ng) & Pre-extinction CFC & No effect & [189] \\
\hline Male Wistar rats & $\mathrm{CeA}$ & OXT $(3 \mathrm{ng} / 0.3 \mu \mathrm{L})$ & Postextinction CFC & -LT extinction & [189] \\
\hline $\begin{array}{l}\text { Male juvenile } \\
\text { Sprague-Dawley rats } \\
\text { (P27) }\end{array}$ & $\mathrm{CeA}$ & TGOT $(7 \mathrm{ng} / 0.5 \mu \mathrm{L})$ & Preacquisition $\mathrm{CFC}$ & - & [201] \\
\hline $\begin{array}{l}\text { Male juvenile } \\
\text { Sprague-Dawley rats } \\
\text { (P27) }\end{array}$ & $\mathrm{CeA}$ & TGOT $(7 \mathrm{ng} / 0.5 \mu \mathrm{L})$ & Postretrieval CFC & No effect & [201] \\
\hline $\begin{array}{l}\text { Male Sprague-Dawley } \\
\text { rats }\end{array}$ & IL-mPFC & OXT $(0.01 \mu \mathrm{g} / 0.5 \mu \mathrm{L})$ & Postretrieval CFC & + & [188] \\
\hline $\begin{array}{l}\text { Male Sprague-Dawley } \\
\text { rats }\end{array}$ & IL-mPFC & WAY-267464 (3 $\mu \mathrm{g} / \mu \mathrm{L})$ & Postretrieval CFC & + & [188] \\
\hline $\begin{array}{l}\text { Male Sprague-Dawley } \\
\text { rats }\end{array}$ & IL-mPFC & TGOT $(7 \mathrm{ng} / 0.5 \mu \mathrm{L})$ & Pre-extinction CFC & + & [200] \\
\hline $\begin{array}{l}\text { Male Sprague-Dawley } \\
\text { rats }\end{array}$ & IL-mPFC & OXTA $(153 \mu \mathrm{mol} / \mathrm{L})$ & Pre-extinction CFC & No effect & [200] \\
\hline $\begin{array}{l}\text { Male juvenile } \\
\text { Spague-Dawley rats } \\
\text { (P27) }\end{array}$ & IL-mPFC & TGOT $(7 \mathrm{ng} / 0.5 \mu \mathrm{L})$ & Postretrieval CFC & No effect & [201] \\
\hline
\end{tabular}

+ Enhancement; - Impairment; AFC, auditory fear conditioning; BLA, amygdala basolateral complex; CeA, central amygdala; CDFC, cue-dependent fear conditioning extinction test; CFC, contextual fear conditioning; i.c.v., intracerebroventricular administration; IL-mPFC, infralimbic area of the medial prefrontal cortex; IN, intra-nasal administration; i.p., intraperitoneal administration; LT, long-term extinction; OXTA, oxytocin antagonist; OXT, synthetic oxytocin; P27, post-natal day 27; SPS, single prolonged stress procedure; TGOT, oxytocin agonist; WAY-267464, oxytocin agonist.

Table 2. Summary of clinical studies assessing the OXT system manipulation effects on fear extinction.

\begin{tabular}{|c|c|c|c|c|c|c|}
\hline $\begin{array}{l}\text { Subjects } \\
\text { (Number) }\end{array}$ & Study Design & $\begin{array}{c}\text { Route of } \\
\text { Administration } \\
\end{array}$ & $\begin{array}{c}\text { Drug } \\
\text { Administered } \\
\end{array}$ & $\begin{array}{c}\text { Time of } \\
\text { Administration }\end{array}$ & $\begin{array}{l}\text { Effect on Fear } \\
\text { Extinction }\end{array}$ & Reference \\
\hline $\begin{array}{l}\text { Healthy } \\
\text { volunteers } \\
(44)\end{array}$ & $\begin{array}{c}\text { Double-blind } \\
\text { Placebo-controlled } \\
\text { study }\end{array}$ & IN & OXT (24 IU) & Pre-extinction & $\begin{array}{c}\text { - At the beginning of } \\
\text { extinction } \\
\text { training } \\
\text { No effect in the middle } \\
\text { phase } \\
\text { +in the late phase }\end{array}$ & [184] \\
\hline $\begin{array}{l}\text { Healthy } \\
\text { volunteer } \\
\text { (62) }\end{array}$ & $\begin{array}{c}\text { Double-blind } \\
\text { Placebo-controlled } \\
\text { study }\end{array}$ & IN & OXT (24 IU) & $\begin{array}{c}\text { Post- } \\
\text { conditioning and } \\
\text { Pre-extinction }\end{array}$ & $\begin{array}{l}\text {-At the beginning of } \\
\text { extinction } \\
\text { training } \\
\text { +in the late phase }\end{array}$ & [73] \\
\hline $\begin{array}{l}\text { Healthy } \\
\text { volunteers } \\
\text { (61) }\end{array}$ & $\begin{array}{c}\text { Double-blind } \\
\text { Placebo-controlled } \\
\text { study }\end{array}$ & IN & OXT (40 IU) & $\begin{array}{c}\text { Post- } \\
\text { conditioning }\end{array}$ & + & [219] \\
\hline $\begin{array}{l}\text { Healthy } \\
\text { volunteers } \\
\text { (15) }\end{array}$ & $\begin{array}{c}\text { Double-blind } \\
\text { Placebo-controlled } \\
\text { study }\end{array}$ & IN & OXT (27 IU) & $\begin{array}{c}\text { Pre- } \\
\text { conditioning }\end{array}$ & No effect & [65] \\
\hline $\begin{array}{l}\text { SAD } \\
\text { Patients } \\
(25)\end{array}$ & $\begin{array}{c}\text { Double-blind } \\
\text { Placebo-controlled } \\
\text { study }\end{array}$ & IN & OXT (24 IU) & $\begin{array}{l}\text { Pre-exposure } \\
\text { therapy }\end{array}$ & $\begin{array}{l}+ \text { (in combination with } \\
\text { exposure therapy) }\end{array}$ & [220] \\
\hline $\begin{array}{l}\text { Arachnophobic } \\
\text { Patients } \\
\text { (23) }\end{array}$ & $\begin{array}{c}\text { Double-blind } \\
\text { Placebo-controlled } \\
\text { study }\end{array}$ & IN & OXT (24 IU) & $\begin{array}{l}\text { Pre-exposure } \\
\text { therapy }\end{array}$ & - & [184] \\
\hline
\end{tabular}


Table 2. Cont.

\begin{tabular}{|c|c|c|c|c|c|c|}
\hline $\begin{array}{l}\text { Subjects } \\
\text { (Number) }\end{array}$ & Study Design & $\begin{array}{c}\text { Route of } \\
\text { Administration }\end{array}$ & $\begin{array}{c}\text { Drug } \\
\text { Administered }\end{array}$ & $\begin{array}{c}\text { Time of } \\
\text { Administration }\end{array}$ & $\begin{array}{l}\text { Effect on Fear } \\
\text { Extinction }\end{array}$ & Reference \\
\hline $\begin{array}{l}\text { PTSD } \\
\text { Patients } \\
(37) \\
\text { vs. } \\
\text { Healthy } \\
\text { Subjects } \\
(40)\end{array}$ & $\begin{array}{c}\text { Placebo-controlled } \\
\text { Crossover } \\
\text { study }\end{array}$ & IN & OXT (40 IU) & $\begin{array}{l}\text { Pre-exposure } \\
\text { therapy }\end{array}$ & $\begin{array}{l}+ \text { (in combination with } \\
\text { exposure therapy) }\end{array}$ & [68] \\
\hline $\begin{array}{l}\text { PTSD } \\
\text { Patients } \\
(17)\end{array}$ & $\begin{array}{c}\text { Double-blind } \\
\text { Placebo-controlled } \\
\text { study }\end{array}$ & IN & OXT (40 IU) & $\begin{array}{l}\text { Pre-exposure } \\
\text { therapy }\end{array}$ & - & [30] \\
\hline $\begin{array}{l}\text { PTSD } \\
\text { Patients } \\
(\text { range = 37-41) }\end{array}$ & $\begin{array}{c}\text { Double-blind } \\
\text { Placebo-controlled } \\
\text { study }\end{array}$ & IN & $\begin{array}{l}\text { OXT (40 IU- } \\
\text { single dose) }\end{array}$ & Pre-fMRI & - & [72] \\
\hline $\begin{array}{l}\text { PTSD } \\
\text { Patients } \\
(107)\end{array}$ & $\begin{array}{c}\text { Double-blind } \\
\text { Placebo-controlled } \\
\text { study }\end{array}$ & IN & $\begin{array}{c}\text { OXT (40 IU- } \\
\text { multiple doses) }\end{array}$ & Post-trauma & + & {$[72]$} \\
\hline
\end{tabular}

+ Enhancement; - Impairment; IN, intranasal administration; OXT, synthetic oxytocin; fMRI, functional magnetic resonance imaging; IU, international units.

\section{Challenges and Perspectives on OXT Research and Therapeutic Exploitation}

Fear extinction is an adaptive form of learning allowing inhibition of the expression of conditioned fear responses to changed environmental contingencies. Failure of extinction can lead to excessive fear, as in some forms of trauma- and anxiety-related disorders. Such disorders are often treated with exposure therapies conceptually based upon fear extinction. However, these therapies show some limits, as they tend to produce transient fear reduction that is bound to the context in which the therapy is administered. One strategy to improve exposure therapies is to associate them with adjunctive pharmacological agents, such as antidepressants (SSRIs), D-cycloserine, glucocorticoids (cortisol), and $\alpha 2$-adrenoceptor antagonists (yohimbine) [27]. Recent research, both in animal models and human subjects, suggests that OXT has anxiolytic effects and may modulate fear extinction. Accordingly, OXT might be considered as an adjunctive treatment to extinction-based therapies. Here, we reviewed recent studies that addressed this issue, focusing on the OXT effects on supposed cerebral networks underlying fear extinction. OXT modulates fear memory extinction, acting mainly on GABAergic neurons of BLA, CeA, and IL. However, more data are needed to find out how OXT acts on extinction neurocircuits. In fact, there is evidence for both extinction-impairing and extinction-improving effects. Increasing local OXT neurotransmission during traumatic events may prevent the formation of fear memories, whereas OXT treatment before fear extinction training cannot be excluded to even delay and impair fear extinction. Since treatment before extinction training would be the comparable time point for psychotherapy in fear-related disorder patients, caution is needed before recommending OXT for the add-on treatment of these disorders, especially in trauma of a non-social nature. Most human studies have used intranasally administered OXT, a noninvasive route, but nasal sprays are limited in terms of dosage control of dosage, absorption, and drug response [221]. Thus, further animal studies are necessary to examine doses, timing of administration, gender dependence of efficacy, and to develop study the timing of OXT effects. Moreover, the signal transduction pathways regulating OXTR expression and binding in each brain region must be clarified. Finally, a specific analysis of the role of hippocampal OXT in nonsocial fear extinction seems to be necessary.

Evidence reviewed here demonstrates that fear extinction depends on complex networks that include interactions between multiple amygdaloid parallel circuits co-ordinated by hippocampal and mPFC activity. Despite these recent advances, several questions remain. For instance, although interneurons are a small cell population in the MPFC and amygdaloid nuclei, they are critical for inhibition. Thus, defining the specific roles of several interneuron classes in circuits underpinning fear extinction will provide a clearer 
understanding of these circuits. Moreover, hippocampal-mPFC-amygdala circuits mediate context dependence of fear memories after extinction; however, future studies of context processing in various psychiatric disorders seem necessary. As the neural networks underpinning fear extinction are evolutionarily conserved circuits, a detailed understanding of these circuits will allow the development of more effective approaches to treat the disorders caused by dysfunctions in these circuits.

Author Contributions: Writing—original draft preparation, E.B., A.C. and B.R.; writing-review and editing, M.B.P., P.B., A.R. and G.P.; funding acquisition, G.P., M.B.P. and P.B. All authors have read and agreed to the published version of the manuscript.

Funding: This research was funded by Fondazione Ente Cassa di Risparmio di Firenze (grant number PATRIZIOBLANDINABANDO2019FCRF20 awarded to P.B. and 58516_BANDOCONGIUNTO_ UNIFICRF awarded to M.B.P.) and University of Florence intra-mural grants awarded to G.P.

Institutional Review Board Statement: Not applicable.

Informed Consent Statement: Not applicable.

Conflicts of Interest: The authors declare no conflict of interest.

\section{Abbreviations}

$\begin{array}{ll}\text { AFC } & \text { auditory fear conditioning } \\ \text { AN } & \text { accessory nuclei } \\ \text { ARC } & \text { arcuate nucleus } \\ \text { AVP } & \text { vasopressin } \\ \text { BA } & \text { basal amygdala } \\ \text { BLA } & \text { basolateral amygdala } \\ \text { BNST } & \text { bed nucleus of the stria terminalis } \\ \text { CCK } & \text { cholecystokinin } \\ \text { CDFC } & \text { cued-dependent fear conditioning } \\ \text { CeA } & \text { central amygdala } \\ \text { CeL } & \text { central lateral amygdala } \\ \text { CeM } & \text { central medial amygdala } \\ \text { CFC } & \text { contextual fear conditioning } \\ \text { CS } & \text { conditioned stimulus } \\ \text { dACC } & \text { dorsal anterior cingulate cortex } \\ \text { fMRI } & \text { functional magnetic resonance imaging } \\ \text { HPA } & \text { hypothalamus pituitary axis } \\ \text { IL } & \text { infralimbic area } \\ \text { IN } & \text { intranasal } \\ \text { ITCs } & \text { intercalated cell masses } \\ \text { LA } & \text { lateral amygdala } \\ \text { ME } & \text { median eminence } \\ \text { mPFC } & \text { medial prefrontal cortex } \\ \text { NTS } & \text { nucleus of the solitary tract } \\ \text { OXT } & \text { oxytocin } \\ \text { OXTR } & \text { OXT receptor } \\ \text { PAG } & \text { periaqueductal gray } \\ \text { PL } & \text { prelimbic area } \\ \text { PTSD } & \text { post-traumatic stress disorder } \\ \text { PVN } & \text { paraventricular nucleus } \\ \text { SAD } & \text { social anxiety disorders } \\ \text { SON } & \text { supraoptic nucleus } \\ \text { SPS } & \text { single prolonged stress } \\ \text { TRPV1 } & \text { transient receptor potential vanilloid-1 receptor } \\ \text { US } & \text { unconditioned stimulus } \\ \text { VMH } & \text { ventromedial nucleus of the hypothalamus } \\ \text { VTA } & \text { ventral tegmental area } \\ & \end{array}$




\section{References}

1. Alberini, C.M.; Ledoux, J.E. Memory reconsolidation. Curr. Biol. 2013, 23, R746-R750. [CrossRef] [PubMed]

2. VanElzakker, M.B.; Dahlgren, M.K.; Davis, F.C.; Dubois, S.; Shin, L.M. From Pavlov to PTSD: The extinction of conditioned fear in rodents, humans, and anxiety disorders. Neurobiol. Learn. Mem. 2014, 113, 3-18. [CrossRef]

3. Gustavsson, A.; Svensson, M.; Jacobi, F.; Allgulander, C.; Alonso, J.; Beghi, E.; Dodel, R.; Ekman, M.; Faravelli, C.; Fratiglioni, L.; et al. Cost of disorders of the brain in Europe 2010. Eur. Neuropsychopharmacol. 2011, 21, 718-779. [CrossRef]

4. Liberzon, I.; Sripada, C.S. The functional neuroanatomy of PTSD: A critical review. Prog. Brain Res. 2008, 167, 151-169. [PubMed]

5. Wittchen, H.U.; Jacobi, F.; Rehm, J.; Gustavsson, A.; Svensson, M.; Jönsson, B.; Olesen, J.; Allgulander, C.; Alonso, J.; Faravelli, C.; et al. The size and burden of mental disorders and other disorders of the brain in Europe 2010. Eur. Neuropsychopharmacol. 2011, 21, 655-679. [CrossRef]

6. Shin, L.M.; Handwerger, K. Is posttraumatic stress disorder a stress-induced fear circuitry disorder? J. Trauma Stress 2009, 22, 409-415. [CrossRef] [PubMed]

7. Ehlers, A.; Clark, D.M. A cognitive model of posttraumatic stress disorder. Behav. Res. Ther. 2000, 38, 319-345. [CrossRef]

8. Lissek, S.; Powers, A.S.; McClure, E.B.; Phelps, E.A.; Woldehawariat, G.; Grillon, C.; Pine, D.S. Classical fear conditioning in the anxiety disorders: A meta-analysis. Behav. Res. Ther. 2005, 43, 1391-1424. [CrossRef] [PubMed]

9. Delgado, M.R.; Olsson, A.; Phelps, E.A. Extending animal models of fear conditioning to humans. Biol. Psychol. 2006, 73, 39-48. [CrossRef]

10. Parsons, R.G.; Ressler, K.J. Implications of memory modulation for post-traumatic stress and fear disorders. Nat. Neurosci. 2013, 16, 146-153. [CrossRef] [PubMed]

11. Fendt, M.; Fanselow, M.S. The neuroanatomical and neurochemical basis of conditioned fear. Neurosci. Biobehav. Rev. 1999, 23, 743-760. [CrossRef]

12. Sacchetti, B.; Lorenzini, C.A.; Baldi, E.; Tassoni, G.; Bucherelli, C. Memorization of contextual and CS conditioned fear response (freezing) in a one-trial acquisition paradigm. Arch. Ital. Biol. 1999, 137, 235-248.

13. Sacchetti, B.; Lorenzini, C.A.; Baldi, E.; Tassoni, G.; Bucherelli, C. Auditory thalamus, dorsal hippocampus, basolateral amygdala, and perirhinal cortex role in the consolidation of conditioned freezing to context and to acoustic conditioned stimulus in the rat. $J$. Neurosci. 1999, 19, 9570-9578. [CrossRef] [PubMed]

14. Ney, L.J.; Wade, M.; Reynolds, A.; Zuj, D.V.; Dymond, S.; Matthews, A.; Felmingham, K.L. Critical evaluation of current data analysis strategies for psychophysiological measures of fear conditioning and extinction in humans. Int. J. Psychophysiol. 2018, 134, 95-107. [CrossRef]

15. LeDoux, J.E. Emotion circuits in the brain. Annu. Rev. Neurosci. 2000, 23, 155-184. [CrossRef] [PubMed]

16. McGaugh, J.L. Memory-A century of consolidation. Science 2000, 287, 248-251. [CrossRef]

17. Abel, T.; Lattal, K.M. Molecular mechanisms of memory acquisition, consolidation and retrieval. Curr. Opin. Neurobiol. 2001, 11, 180-187. [CrossRef]

18. Josselyn, S.A.; Köhler, S.; Frankland, P.W. Finding the engram. Nat. Rev. Neurosci. 2015, 16, 521-534. [CrossRef]

19. Eisenberg, M.; Kobilo, T.; Berman, D.E.; Dudai, Y. Stability of retrieved memory: Inverse correlation with trace dominance. Science 2003, 301, 1102-1104. [CrossRef]

20. Pedreira, M.E.; Maldonado, H. Protein synthesis subserves reconsolidation or extinction depending on reminder duration. Neuron 2003, 38, 863-869. [CrossRef]

21. Suzuki, A.; Josselyn, S.A.; Frankland, P.W.; Masushige, S.; Silva, A.J.; Kida, S. Memory reconsolidation and extinction have distinct temporal and biochemical signatures. J. Neurosci. 2004, 24, 4787-4795. [CrossRef]

22. Bouton, M.E.; Mineka, S.; Barlow, D.H. A modern learning theory perspective on the etiology of panic disorder. Psychol. Rev. 2001, 108, 4-32. [CrossRef]

23. Rothbaum, B.O.; Davis, M. Applying learning principles to the treatment of post-trauma reactions. Ann. N. Y. Acad. Sci. 2003, 1008, 112-121. [CrossRef]

24. Craske, M.G.; Kircanski, K.; Zelikowsky, M.; Mystkowski, J.; Chowdhury, N.; Baker, A. Optimizing inhibitory learning during exposure therapy. Behav. Res. Ther. 2008, 46, 5-27. [CrossRef]

25. Choy, Y.; Fyer, A.J.; Lipsitz, J.D. Treatment of specific phobia in adults. Clin. Psychol. Rev. 2007, 27, 266-286. [CrossRef] [PubMed]

26. Bandelow, B.; Sher, L.; Bunevicius, R.; Hollander, E.; Kasper, S.; Zohar, J.; Möller, H.J.; WFSBP Task Force on Mental Disorders in Primary Care; WFSBP Task Force on Anxiety Disorders, OCD and PTSD. Guidelines for the pharmacological treatment of anxiety disorders, obsessive-compulsive disorder and posttraumatic stress disorder in primary care. Int. J. Psychiatry Clin. Pract. 2012, 16, 77-84. [CrossRef] [PubMed]

27. Singewald, N.; Schmuckermair, C.; Whittle, N.; Holmes, A.; Ressler, K.J. Pharmacology of cognitive enhancers for exposure-based therapy of fear, anxiety and trauma-related disorders. Pharmacol. Ther. 2015, 149, 150-190. [CrossRef]

28. Bukalo, O.; Pinard, C.R.; Holmes, A. Mechanisms to medicines: Elucidating neural and molecular substrates of fear extinction to identify novel treatments for anxiety disorders. Br. J. Pharmacol. 2014, 171, 4690-4718. [CrossRef]

29. Schmidt, S.D.; Costa, A.; Rani, B.; Godfried Nachtigall, E.; Passani, M.B.; Carta, F.; Nocentini, A.; de Carvalho Myskiw, J.; Furini, C.R.G.; Supuran, C.T.; et al. The role of carbonic anhydrases in extinction of contextual fear memory. Proc. Natl. Acad. Sci. USA 2020, 117, 16000-16008. [CrossRef] [PubMed] 
30. Flanagan, J.C.; Sippel, L.M.; Wahlquist, A.; Moran-Santa Maria, M.M.; Back, S.E. Augmenting Prolonged Exposure therapy for PTSD with intranasal oxytocin: A randomized, placebo-controlled pilot trial. J. Psychiatr. Res. 2018, 98, 64-69. [CrossRef]

31. Stoehr, J.D.; Cramer, C.P.; North, W.G. Oxytocin and vasopressin hexapeptide fragments have opposing influences on conditioned freezing behavior. Psychoneuroendocrinology 1992, 17, 267-271. [CrossRef]

32. Li, K.; Nakajima, M.; Ibañez-Tallon, I.; Heintz, N. A Cortical Circuit for Sexually Dimorphic Oxytocin-Dependent Anxiety Behaviors. Cell 2016, 167, 60.e11-72.e11. [CrossRef] [PubMed]

33. Mitre, M.; Marlin, B.J.; Schiavo, J.K.; Morina, E.; Norden, S.E.; Hackett, T.A.; Aoki, C.J.; Chao, M.V.; Froemke, R.C. A Distributed Network for Social Cognition Enriched for Oxytocin Receptors. J. Neurosci. 2016, 36, 2517-2535. [CrossRef] [PubMed]

34. Rogers, C.N.; Ross, A.P.; Sahu, S.P.; Siegel, E.R.; Dooyema, J.M.; Cree, M.A.; Stopa, E.G.; Young, L.J.; Rilling, J.K.; Albers, H.E.; et al. Oxytocin- and arginine vasopressin-containing fibers in the cortex of humans, chimpanzees, and rhesus macaques. Am. J. Primatol. 2018, 80, e22875. [CrossRef]

35. Ohlsson, B.; Truedsson, M.; Djerf, P.; Sundler, F. Oxytocin is expressed throughout the human gastrointestinal tract. Regul. Pept. 2006, 135, 7-11. [CrossRef]

36. Ding, C.; Leow, M.K.; Magkos, F. Oxytocin in metabolic homeostasis: Implications for obesity and diabetes management. Obes. Rev. 2019, 20, 22-40. [CrossRef] [PubMed]

37. Grinevich, V.; Knobloch-Bollmann, H.S.; Eliava, M.; Busnelli, M.; Chini, B. Assembling the Puzzle: Pathways of Oxytocin Signaling in the Brain. Biol. Psychiatry 2016, 79, 155-164. [CrossRef] [PubMed]

38. George, J.M. Immunoreactive vasopressin and oxytocin: Concentration in individual human hypothalamic nuclei. Science 1978, 200, 342-343. [CrossRef]

39. Bargmann, W.; Scharrer, E. The site of origin of the hormones of the posterior pituitary. Am. Sci. 1951, 39, $255-259$.

40. Knobloch, H.S.; Charlet, A.; Hoffmann, L.C.; Eliava, M.; Khrulev, S.; Cetin, A.H.; Osten, P.; Schwarz, M.K.; Seeburg, P.H.; Stoop, R.; et al. Evoked axonal oxytocin release in the central amygdala attenuates fear response. Neuron 2012, 73, 553-566. [CrossRef] [PubMed]

41. Sofroniew, M.V. Morphology of vasopressin and oxytocin neurones and their central and vascular projections. Prog. Brain Res. 1983, 60, 101-114.

42. Dölen, G.; Darvishzadeh, A.; Huang, K.W.; Malenka, R.C. Social reward requires coordinated activity of nucleus accumbens oxytocin and serotonin. Nature 2013, 501, 179-184. [CrossRef]

43. Menon, R.; Grund, T.; Zoicas, I.; Althammer, F.; Fiedler, D.; Biermeier, V.; Bosch, O.J.; Hiraoka, Y.; Nishimori, K.; Eliava, M.; et al. Oxytocin Signaling in the Lateral Septum Prevents Social Fear during Lactation. Curr. Biol. 2018, 28, 1066-1078.e6. [CrossRef]

44. Mittaud, P.; Labourdette, G.; Zingg, H.; Guenot-Di Scala, D. Neurons modulate oxytocin receptor expression in rat cultured astrocytes: Involvement of TGF-beta and membrane components. Glia 2002, 37, 169-177. [CrossRef] [PubMed]

45. Knobloch, H.S.; Grinevich, V. Evolution of oxytocin pathways in the brain of vertebrates. Front. Behav. Neurosci. $2014,8,31$. [CrossRef]

46. Hasan, M.T.; Althammer, F.; Silva da Gouveia, M.; Goyon, S.; Eliava, M.; Lefevre, A.; Kerspern, D.; Schimmer, J.; Raftogianni, A.; Wahis, J.; et al. A Fear Memory Engram and Its Plasticity in the Hypothalamic Oxytocin System. Neuron 2019, 103, 133-146.e8. [CrossRef] [PubMed]

47. Brownstein, M.J.; Russell, J.T.; Gainer, H. Synthesis, transport, and release of posterior pituitary hormones. Science 1980, 207, 373-378. [CrossRef]

48. Sheldrick, E.L.; Flint, A.P. Post-translational processing of oxytocin-neurophysin prohormone in the ovine corpus luteum: Activity of peptidyl glycine alpha-amidating mono-oxygenase and concentrations of its cofactor, ascorbic acid. J. Endocrinol. 1989, 122, 313-322. [CrossRef] [PubMed]

49. Landgraf, R.; Jones, M. Memorial Lecture. Intracerebrally released vasopressin and oxytocin: Measurement, mechanisms and behavioural consequences. J. Neuroendocrinol. 1995, 7, 243-253. [CrossRef]

50. Sjöholm, I. Oxytocinase and its possible significance in the degradation of oxytocin during pregnancy. FEBS Lett. 1969, 4, 135-139. [CrossRef]

51. Tobin, V.A.; Arechaga, G.; Brunton, P.J.; Russell, J.A.; Leng, G.; Ludwig, M.; Douglas, A.J. Oxytocinase in the female rat hypothalamus: A novel mechanism controlling oxytocin neurones during lactation. J. Neuroendocrinol. 2014, 26, 205-216. [CrossRef]

52. Inoue, T.; Kimura, T.; Azuma, C.; Inazawa, J.; Takemura, M.; Kikuchi, T.; Kubota, Y.; Ogita, K.; Saji, F. Structural organization of the human oxytocin receptor gene. J. Biol. Chem. 1994, 269, 32451-32456. [CrossRef]

53. Verbalis, J.G.; Mangione, M.P.; Stricker, E.M. Oxytocin produces natriuresis in rats at physiological plasma concentrations. Endocrinology 1991, 128, 1317-1322. [CrossRef] [PubMed]

54. Manning, M.; Stoev, S.; Chini, B.; Durroux, T.; Mouillac, B.; Guillon, G. Peptide and non-peptide agonists and antagonists for the vasopressin and oxytocin V1a, V1b, V2 and OT receptors: Research tools and potential therapeutic agents. Prog. Brain Res. 2008, $170,473-512$.

55. Daza, O.D.; Lewicka, M.; Larhammar, D. The oxytocin/vasopressin receptor family has at least five members in the gnathostome lineage, inclucing two distinct V2 subtypes. Gen. Comp. Endocrinol. 2012, 175, 135-143. [CrossRef] 
56. Nersesyan, Y.; Demirkhanyan, L.; Cabezas-Bratesco, D.; Oakes, V.; Kusuda, R.; Dawson, T.; Sun, X.; Cao, C.; Cohen, A.M.; Chelluboina, B.; et al. Oxytocin Modulates Nociception as an Agonist of Pain-Sensing TRPV1. Cell Rep. 2017, 21, 1681-1691. [CrossRef]

57. Wee, C.L.; Nikitchenko, M.; Wang, W.C.; Luks-Morgan, S.J.; Song, E.; Gagnon, J.A.; Randlett, O.; Bianco, I.H.; Lacoste, A.M.B.; Glushenkova, E.; et al. Zebrafish oxytocin neurons drive nocifensive behavior via brainstem premotor targets. Nat. Neurosci. 2019, 22, 1477-1492. [CrossRef]

58. Meguro, Y.; Miyano, K.; Hirayama, S.; Yoshida, Y.; Ishibashi, N.; Ogino, T.; Fujii, Y.; Manabe, S.; Eto, M.; Nonaka, M.; et al. Neuropeptide oxytocin enhances $\mu$ opioid receptor signaling as a positive allosteric modulator. J. Pharmacol. Sci. 2018, 137, 67-75. [CrossRef] [PubMed]

59. Engelmann, M.; Landgraf, R. Microdialysis administration of vasopressin into the septum improves social recognition in Brattleboro rats. Physiol. Behav. 1994, 55, 145-149. [CrossRef]

60. Neumann, I.D. Involvement of the brain oxytocin system in stress coping: Interactions with the hypothalamo-pituitary-adrenal axis. Prog. Brain Res. 2002, 139, 147-162. [PubMed]

61. Amico, J.A.; Mantella, R.C.; Vollmer, R.R.; Li, X. Anxiety and stress responses in female oxytocin deficient mice. J. Neuroendocrinol. 2004, 16, 319-324. [CrossRef]

62. Zhu, L.; Onaka, T. Involvement of medullary A2 noradrenergic neurons in the activation of oxytocin neurons after conditioned fear stimuli. Eur. J. Neurosci. 2002, 16, 2186-2198. [CrossRef]

63. Martinon, D.; Paulina Lis, P.; Roman, A.N.; Tornesi, P.; Applebey, S.V.; Buechner, G.; Olivera, V.; Dabrowska, J. Oxytocin receptors in the dorsolateral bed nucleus of the stria terminalis (BNST) bias fear learning toward temporally predictable cued fear. Transl. Psychiatry 2019, 9, 140. [CrossRef] [PubMed]

64. Meyer-Lindenberg, A.; Domes, G.; Kirsch, P.; Heinrichs, M. Oxytocin and vasopressin in the human brain: Social neuropeptides for translational medicine. Nat. Rev. Neurosci. 2011, 12, 524-538. [CrossRef]

65. Kirsch, P.; Esslinger, C.; Chen, Q.; Mier, D.; Lis, S.; Siddhanti, S.; Gruppe, H.; Mattay, V.S.; Gallhofer, B.; Meyer-Lindenberg, A. Oxytocin modulates neural circuitry for social cognition and fear in humans. J. Neurosci. 2005, 25, 11489-11493. [CrossRef]

66. Labuschagne, I.; Phan, K.L.; Wood, A.; Angstadt, M.; Chua, P.; Heinrichs, M.; Stout, J.C.; Nathan, P.J. Oxytocin attenuates amygdala reactivity to fear in generalized social anxiety disorder. Neuropsychopharmacology 2010, 35, 2403-2413. [CrossRef]

67. Gorka, S.M.; Fitzgerald, D.A.; Labuschagne, I.; Hosanagar, A.; Wood, A.G.; Nathan, P.J.; Phan, K.L. Oxytocin modulation of amygdala functional connectivity to fearful faces in generalized social anxiety disorder. Neuropsychopharmacology 2015, 40, 278-286. [CrossRef]

68. Koch, S.B.J.; van Zuiden, M.; Nawijn, L.; Frijling, J.L.; Veltman, D.J.; Olff, M. Intranasal Oxytocin Normalizes Amygdala Functional Connectivity in Posttraumatic Stress Disorder. Neuropsychopharmacology 2016, 41, 2041-2051. [CrossRef] [PubMed]

69. Labuschagne, I.; Phan, K.L.; Wood, A.; Angstadt, M.; Chua, P.; Heinrichs, M.; Stout, J.C.; Nathan, P.J. Medial frontal hyperactivity to sad faces in generalized social anxiety disorder and modulation by oxytocin. Int. J. Neuropsychopharmacol. 2012, 15, 883-896. [CrossRef] [PubMed]

70. Dodhia, S.; Hosanagar, A.; Fitzgerald, D.A.; Labuschagne, I.; Wood, A.G.; Nathan, P.J.; Phan, K.L. Modulation of resting-state amygdala-frontal functional connectivity by oxytocin in generalized social anxiety disorder. Neuropsychopharmacology 2014, 39, 2061-2069. [CrossRef] [PubMed]

71. Frijling, J.L.; van Zuiden, M.; Koch, S.B.; Nawijn, L.; Goslings, J.C.; Luitse, J.S.; Biesheuvel, T.H.; Honig, A.; Bakker, F.C.; Denys, D.; et al. Efficacy of oxytocin administration early after psychotrauma in preventing the development of PTSD: Study protocol of a randomized controlled trial. BMC Psychiatry 2014, 14, 92. [CrossRef]

72. Frijling, J.L. Preventing PTSD with oxytocin: Effects of oxytocin administration on fear neurocircuitry and PTSD symptom development in recently trauma-exposed individuals. Eur. J. Psychotraumatol. 2017, 8, 1302652. [CrossRef]

73. Eckstein, M.; Becker, B.; Scheele, D.; Scholz, C.; Preckel, K.; Schlaepfer, T.E.; Grinevich, V.; Kendrick, K.M.; Maier, W.; Hurlemann, R. Oxytocin facilitates the extinction of conditioned fear in humans. Biol. Psychiatry 2015, 78, 194-202. [CrossRef]

74. Bouton, M.E. Context and behavioral processes in extinction. Learn Mem. 2004, 11, 485-494. [CrossRef]

75. Myers, K.M.; Davis, M. Mechanisms of fear extinction. Mol. Psychiatry 2007, 12, 120-150. [CrossRef]

76. Quirk, G.J.; Mueller, D. Neural mechanisms of extinction learning and retrieval. Neuropsychopharmacology 2008, 33, 56-72. [CrossRef]

77. Baldi, E.; Bucherelli, C. Brain sites involved in fear memory reconsolidation and extinction of rodents. Neurosci. Biobehav. Rev. 2015, 53, 160-190. [CrossRef] [PubMed]

78. Raio, C.M.; Phelps, E.A. The influence of acute stress on the regulation of conditioned fear. Neurobiol. Stress 2015, 1, 134-146. [CrossRef]

79. Maren, S.; Holmes, A. Stress and Fear Extinction. Neuropsychopharmacology 2016, 41, 58-79. [CrossRef]

80. Stockhorst, U.; Antov, M.I. Modulation of Fear Extinction by Stress, Stress Hormones and Estradiol: A Review. Front. Behav. Neurosci. 2015, 9, 359. [CrossRef]

81. Long, V.A.; Fanselow, M.S. Stress-enhanced fear learning in rats is resistant to the effects of immediate massed extinction. Stress 2012, 15, 627-636. [CrossRef]

82. Yamamoto, S.; Morinobu, S.; Takei, S.; Fuchikami, M.; Matsuki, A.; Yamawaki, S.; Liberzon, I. Single prolonged stress: Toward an animal model of posttraumatic stress disorder. Depress. Anxiety 2009, 26, 1110-1117. [CrossRef] 
83. Kohda, K.; Harada, K.; Kato, K.; Hoshino, A.; Motohashi, J.; Yamaji, T.; Morinobu, S.; Matsuoka, N.; Kato, N. Glucocorticoid receptor activation is involved in producing abnormal phenotypes of single-prolonged stress rats: A putative post-traumatic stress disorder model. Neuroscience 2007, 148, 22-33. [CrossRef]

84. Wang, S.C.; Lin, C.C.; Tzeng, N.S.; Tung, C.S.; Liu, Y.P. Effects of oxytocin on prosocial behavior and the associated profiles of oxytocinergic and corticotropin-releasing hormone receptors in a rodent model of posttraumatic stress disorder. J. Biomed. Sci. 2019, 26, 26. [CrossRef]

85. Ledgerwood, L.; Richardson, R.; Cranney, J. Effects of D-cycloserine on extinction of conditioned freezing. Behav. Neurosci. 2003, 117, 341-349. [CrossRef] [PubMed]

86. Laurent, V.; Westbrook, R.F. Distinct contributions of the basolateral amygdala and the medial prefrontal cortex to learning and relearning extinction of context conditioned fear. Learn Mem. 2008, 15, 657-666. [CrossRef] [PubMed]

87. Sierra-Mercado, D.; Padilla-Coreano, N.; Quirk, G.J. Dissociable roles of prelimbic and infralimbic cortices, ventral hippocampus, and basolateral amygdala in the expression and extinction of conditioned fear. Neuropsychopharmacology 2011, 36, 529-538. [CrossRef]

88. Holmes, N.M.; Parkes, S.L.; Killcross, A.S.; Westbrook, R.F. The basolateral amygdala is critical for learning about neutral stimuli in the presence of danger, and the perirhinal cortex is critical in the absence of danger. J. Neurosci. 2013, 33, 13112-13125. [CrossRef] [PubMed]

89. Falls, W.A.; Miserendino, M.J.; Davis, M. Extinction of fear-potentiated startle: Blockade by infusion of an NMDA antagonist into the amygdala. J. Neurosci. 1992, 12, 854-863. [CrossRef] [PubMed]

90. Myskiw, J.C.; Izquierdo, I.; Furini, C.R. Modulation of the extinction of fear learning. Brain Res. Bull. 2014, 105, 61-69. [CrossRef]

91. Morgan, M.A.; Romanski, L.M.; LeDoux, J.E. Extinction of emotional learning: Contribution of medial prefrontal cortex. Neurosci. Lett. 1993, 163, 109-113. [CrossRef]

92. Kim, J.J.; Fanselow, M.S. Modality-specific retrograde amnesia of fear. Science 1992, 256, 675-677. [CrossRef]

93. Phillips, R.G.; LeDoux, J.E. Differential contribution of amygdala and hippocampus to cued and contextual fear conditioning. Behav. Neurosci. 1992, 106, 274-285. [CrossRef]

94. Milad, M.R.; Quirk, G.J. Fear extinction as a model for translational neuroscience: Ten years of progress. Annu. Rev. Psychol. 2012, 63, 129-151. [CrossRef] [PubMed]

95. Herry, C.; Ciocchi, A.; Senn, V.; Demmou, L.; Müller, C.; Lüthi, A. Switching on and off fear by distinct neuronal circuits. Nature 2008, 454, 600-606. [CrossRef]

96. Herry, C.; Mons, N. Resistance to extinction is associated with impaired immediate early gene induction in medial prefrontal cortex and amygdala. Eur. J. Neurosci. 2004, 20, 781-790. [CrossRef]

97. Muigg, P.; Hetzenauer, A.; Hauer, G.; Hauschild, M.; Gaburro, S.; Frank, E.; Landgraf, R.; Singewald, N. Impaired extinction of learned fear in rats selectively bred for high anxiety-Evidence of altered neuronal processing in prefrontal-amygdala pathways. Eur. J. Neurosci. 2008, 28, 2299-2309. [CrossRef] [PubMed]

98. Muigg, P.; Hetzenauer, A.; Hauer, G.; Hauschild, M.; Gaburro, S.; Frank, E.; Landgraf, R.; Singewald, N. Long-range connectivity defines behavioral specificity of amygdala neurons. Neuron 2014, 81, 428-437.

99. Chhatwal, J.P.; Myers, K.M.; Ressler, K.J.; Davis, M. Regulation of gephyrin and GABAA receptor binding within the amygdala after fear acquisition and extinction. J. Neurosci. 2005, 25, 502-506. [CrossRef]

100. Heldt, S.A.; Ressler, K.J. Training-induced changes in the expression of GABAA-associated genes in the amygdala after the acquisition and extinction of Pavlovian fear. Eur. J. Neurosci. 2007, 26, 3631-3644. [CrossRef]

101. Pedersen, C.A.; Prange, A.J. Induction of maternal behavior in virgin rats after intracerebroventricular administration of oxytocin. Proc. Natl. Acad. Sci. USA 1979, 76, 6661-6665. [CrossRef]

102. Mascagni, F.; McDonald, A.J. Immunohistochemical characterization of cholecystokinin containing neurons in the rat basolateral amygdala. Brain Res. 2003, 976, 171-184. [CrossRef]

103. Duvarci, S.; Pare, D. Amygdala microcircuits controlling learned fear. Neuron 2014, 82, 966-980. [CrossRef]

104. Duvarci, S.; Popa, D.; Paré, D. Central amygdala activity during fear conditioning. J. Neurosci. 2011, 31, 289-294. [CrossRef]

105. Harris, J.A.; Westbrook, R.F. Evidence that GABA transmission mediates context-specific extinction of learned fear. Psychopharmacology 1998, 140, 105-115. [CrossRef]

106. Hart, G.; Harris, J.A.; Westbrook, R.F. Systemic or intra-amygdala injection of a benzodiazepine (midazolam) impairs extinction but spares re-extinction of conditioned fear responses. Learn Mem. 2009, 16, 53-61. [CrossRef]

107. Likhtik, E.; Popa, D.; Apergis-Schoute, J.; Fidacaro, G.A.; Paré, D. Amygdala intercalated neurons are required for expression of fear extinction. Nature 2008, 454, 642-645. [CrossRef]

108. Knapska, E.; Maren, S. Reciprocal patterns of c-Fos expression in the medial prefrontal cortex and amygdala after extinction and renewal of conditioned fear. Learn Mem. 2009, 16, 486-493. [CrossRef]

109. Busti, D.; Geracitano, R.; Whittle, N.; Dalezios, Y.; Mańko, M.; Kaufmann, W.; Sätzler, K.; Singewald, N.; Capogna, M.; Ferraguti, F. Different fear states engage distinct networks within the intercalated cell clusters of the amygdala. J. Neurosci. 2011, 31, 5131-5144. [CrossRef]

110. Amano, T.; Unal, C.T.; Paré, D. Synaptic correlates of fear extinction in the amygdala. Nat. Neurosci. 2010, 13, 489-494. [CrossRef]

111. Huber, D.; Veinante, P.; Stoop, R. Vasopressin and oxytocin excite distinct neuronal populations in the central amygdala. Science 2005, 308, 245-248. [CrossRef] 
112. Cassell, M.D.; Freedman, L.J.; Shi, C. The intrinsic organization of the central extended amygdala. Ann. N. Y. Acad. Sci. 1999, 877, 217-241. [CrossRef] [PubMed]

113. Ciocchi, S.; Herry, C.; Grenier, F.; Wolff, S.B.; Letzkus, J.J.; Vlachos, I.; Ehrlich, I.; Sprengel, R.; Deisseroth, K.; Stadler, M.B.; et al. Encoding of conditioned fear in central amygdala inhibitory circuits. Nature 2010, 468, 277-282. [CrossRef]

114. Haubensak, W.; Kunwar, P.S.; Cai, H.; Ciocchi, S.; Wall, N.R.; Ponnusamy, R.; Biag, J.; Dong, H.W.; Deisseroth, K.; Callaway, E.M.; et al. Genetic dissection of an amygdala microcircuit that gates conditioned fear. Nature 2010, 468, 270-276. [CrossRef] [PubMed]

115. Kim, J.H.; Perry, C.J.; Ganella, D.E.; Madsen, H.B. Postnatal development of neurotransmitter systems and their relevance to extinction of conditioned fear. Neurobiol. Learn. Mem. 2017, 138, 252-270. [CrossRef] [PubMed]

116. Sotres-Bayon, F.; Quirk, G.J. Prefrontal control of fear: More than just extinction. Curr. Opin. Neurobiol. 2010, 20, 231-235. [CrossRef]

117. Corcoran, K.A.; Quirk, G.J. Activity in prelimbic cortex is necessary for the expression of learned, but not innate, fears. J. Neurosci. 2007, 27, 840-844. [CrossRef]

118. Burgos-Robles, A.; Vidal-Gonzalez, I.; Quirk, G.J. Sustained conditioned responses in prelimbic prefrontal neurons are correlated with fear expression and extinction failure. J. Neurosci. 2009, 29, 8474-8482. [CrossRef]

119. Rodriguez-Romaguera, J.; Sotres-Bayon, F.; Mueller, D.; Quirk, G.J. Systemic propranolol acts centrally to reduce conditioned fear in rats without impairing extinction. Biol. Psychiatry 2009, 65, 887-892. [CrossRef]

120. Lemos, J.I.; Resstel, L.B.; Guimarães, F.S. Involvement of the prelimbic prefrontal cortex on cannabidiol-induced attenuation of contextual conditioned fear in rats. Behav. Brain Res. 2010, 207, 105-111. [CrossRef]

121. Orsini, C.A.; Yan, C.; Maren, S. Ensemble coding of context-dependent fear memory in the amygdala. Front. Behav. Neurosci. 2013, 7, 199. [CrossRef]

122. Vertes, R.P. Differential projections of the infralimbic and prelimbic cortex in the rat. Synapse 2004, 51, 32-58. [CrossRef]

123. Likhtik, E.; Pelletier, J.G.; Paz, R.; Paré, D. Prefrontal control of the amygdala. J. Neurosci. 2005, 25, 7429-7437. [CrossRef]

124. Courtin, J.; Chaudun, F.; Rozeske, R.R.; Karalis, N.; Gonzalez-Campo, C.; Wurtz, H.; Abdi, A.; Baufreton, J.; Bienvenu, T.C.; Herry, C. Prefrontal parvalbumin interneurons shape neuronal activity to drive fear expression. Nature 2014, 505, 92-96. [CrossRef] [PubMed]

125. Milad, M.R.; Quirk, G.J. Neurons in medial prefrontal cortex signal memory for fear extinction. Nature 2002, 420, 70-74. [CrossRef] [PubMed]

126. Do-Monte, F.H.; Manzano-Nieves, G.; Quiñones-Laracuente, K.; Ramos-Medina, L.; Quirk, G.J. Revisiting the role of infralimbic cortex in fear extinction with optogenetics. J. Neurosci. 2015, 35, 3607-3615. [CrossRef]

127. Thompson, B.M.; Baratta, M.V.; Biedenkapp, J.C.; Rudy, J.W.; Watkins, L.R.; Maier, S.F. Activation of the infralimbic cortex in a fear context enhances extinction learning. Learn Mem. 2010, 17, 591-599. [CrossRef] [PubMed]

128. Chang, C.H.; Maren, S. Medial prefrontal cortex activation facilitates re-extinction of fear in rats. Learn Mem. 2011, 18, 221-225. [CrossRef]

129. Santini, E.; Quirk, G.J.; Porter, J.T. Fear conditioning and extinction differentially modify the intrinsic excitability of infralimbic neurons. J. Neurosci. 2008, 28, 4028-4036. [CrossRef]

130. Milad, M.R.; Wright, C.I.; Orr, S.P.; Pitman, R.K.; Quirk, G.J.; Rauch, S.L. Recall of fear extinction in humans activates the ventromedial prefrontal cortex and hippocampus in concert. Biol. Psychiatry 2007, 62, 446-454. [CrossRef]

131. Gottfried, J.A.; Dolan, R.J. Human orbitofrontal cortex mediates extinction learning while accessing conditioned representations of value. Nat. Neurosci. 2004, 7, 1144-1152. [CrossRef] [PubMed]

132. Kalisch, R.; Korenfeld, E.; Stephan, K.E.; Weiskopf, N.; Seymour, B.; Dolan, R.J. Context-dependent human extinction memory is mediated by a ventromedial prefrontal and hippocampal network. J. Neurosci. 2006, 26, 9503-9511. [CrossRef] [PubMed]

133. Barrett, J.; Armony, J.L. Influence of trait anxiety on brain activity during the acquisition and extinction of aversive conditioning. Psychol Med. 2009, 39, 255-265. [CrossRef]

134. Phelps, E.A.; Delgado, M.R.; Nearing, K.I.; LeDoux, J.E. Extinction learning in humans: Role of the amygdala and vmPFC. Neuron 2004, 43, 897-905. [CrossRef] [PubMed]

135. Milad, M.R.; Quinn, B.T.; Pitman, R.K.; Orr, S.P.; Fischl, B.; Rauch, S.L. Thickness of ventromedial prefrontal cortex in humans is correlated with extinction memory. Proc. Natl. Acad. Sci. USA 2005, 102, 10706-10711. [CrossRef] [PubMed]

136. Marek, R.; Xu, L.; Sullivan, R.K.P.; Sah, P. Excitatory connections between the prelimbic and infralimbic medial prefrontal cortex show a role for the prelimbic cortex in fear extinction. Nat. Neurosci. 2018, 21, 654-658. [CrossRef]

137. Bukalo, O.; Pinard, C.R.; Silverstein, S.; Brehm, C.; Hartley, N.D.; Whittle, N.; Colacicco, G.; Busch, E.; Patel, S.; Singewald, N.; et al. Prefrontal inputs to the amygdala instruct fear extinction memory formation. Sci. Adv 2015, 1, 2567. [CrossRef]

138. Quirk, G.J.; Likhtik, E.; Pelletier, J.G.; Paré, D. Stimulation of medial prefrontal cortex decreases the responsiveness of central amygdala output neurons. J. Neurosci. 2003, 23, 8800-8807. [CrossRef]

139. An, B.; Kim, J.; Park, K.; Lee, S.; Song, S.; Choi, S. Amount of fear extinction changes its underlying mechanisms. eLife 2017, 6, 2662.e1. [CrossRef]

140. Berretta, S.; Pantazopoulos, H.; Caldera, M.; Pantazopoulos, P.; Paré, D. Infralimbic cortex activation increases c-Fos expression in intercalated neurons of the amygdala. Neuroscience 2005, 132, 943-953. [CrossRef]

141. Giustino, T.F.; Maren, S. The Role of the Medial Prefrontal Cortex in the Conditioning and Extinction of Fear. Front. Behav. Neurosci. 2015, 9, 298. [CrossRef] [PubMed] 
142. Orsini, C.A.; Kim, J.H.; Knapska, E.; Maren, S. Hippocampal and prefrontal projections to the basal amygdala mediate contextual regulation of fear after extinction. J. Neurosci. 2011, 31, 17269-17277. [CrossRef]

143. Orsini, C.A.; Maren, S. Neural and cellular mechanisms of fear and extinction memory formation. Neurosci. Biobehav. Rev. 2012, 36, 1773-1802. [CrossRef] [PubMed]

144. Corcoran, K.A.; Maren, S. Hippocampal inactivation disrupts the acquisition and contextual encoding of fear extinction. J. Neurosci. 2005, 25, 8978-8987. [CrossRef] [PubMed]

145. Xue, L.; Li, Z.D.; Chen, Z.X.; Wang, X.G.; Shi, Y.W.; Zhao, H. Fear response failed to return in AAB extinction paradigm accompanied with increased NR2B and GluR1 per845 in hippocampal CA1. Neuroscience 2014, 260, 1-11. [CrossRef]

146. Berlau, D.J.; McGaugh, J.L. Enhancement of extinction memory consolidation: The role of the noradrenergic and GABAergic systems within the basolateral amygdala. Neurobiol. Learn. Mem. 2006, 86, 123-132. [CrossRef] [PubMed]

147. Corcoran, K.A.; Maren, S. Hippocampal inactivation disrupts contextual retrieval of fear memory after extinction. J. Neurosci. 2001, 21, 1720-1726. [CrossRef] [PubMed]

148. Corcoran, K.A.; Maren, S. Factors regulating the effects of hippocampal inactivation on renewal of conditional fear after extinction. Learn Mem. 2004, 11, 598-603. [CrossRef]

149. Hobin, J.A.; Ji, J.; Maren, S. Ventral hippocampal muscimol disrupts context-specific fear memory retrieval after extinction in rats. Hippocampus 2006, 16, 174-182. [CrossRef]

150. Gabbott, P.L.; Warner, T.A.; Jays, P.R.; Bacon, S.J. Areal and synaptic interconnectivity of prelimbic (area 32), infralimbic (area 25) and insular cortices in the rat. Brain Res. 2003, 993, 59-71. [CrossRef] [PubMed]

151. Delgado, M.R.; Nearing, K.I.; Ledoux, J.E.; Phelps, E.A. Neural circuitry underlying the regulation of conditioned fear and its relation to extinction. Neuron 2008, 59, 829-838. [CrossRef]

152. Mitra, R.; Jadhav, S.; McEwen, B.S.; Vyas, A.; Chattarji, S. Stress duration modulates the spatiotemporal patterns of spine formation in the basolateral amygdala. Proc. Natl. Acad. Sci. USA 2005, 102, 9371-9376. [CrossRef]

153. Vyas, A.; Jadhav, S.; Chattarji, S. Prolonged behavioral stress enhances synaptic connectivity in the basolateral amygdala. Neuroscience 2006, 143, 387-393. [CrossRef] [PubMed]

154. Padival, M.A.; Blume, S.R.; Rosenkranz, J.A. Repeated restraint stress exerts different impact on structure of neurons in the lateral and basal nuclei of the amygdala. Neuroscience 2013, 246, 230-242. [CrossRef] [PubMed]

155. Grillo, C.A.; Risher, M.; Macht, V.A.; Bumgardner, A.L.; Hang, A.; Gabriel, C.; Mocaër, E.; Piroli, G.G.; Fadel, J.R.; Reagan, L.P. Repeated restraint stress-induced atrophy of glutamatergic pyramidal neurons and decreases in glutamatergic efflux in the rat amygdala are prevented by the antidepressant agomelatine. Neuroscience 2015, 284, 430-443. [CrossRef]

156. Maroun, M.; Ioannides, P.J.; Bergman, K.L.; Kavushansky, A.; Holmes, A.; Wellman, C.L. Fear extinction deficits following acute stress associate with increased spine density and dendritic retraction in basolateral amygdala neurons. Eur. J. Neurosci. 2013, 38, 2611-2620. [CrossRef] [PubMed]

157. Maroun, M.; Richter-Levin, G. Exposure to acute stress blocks the induction of long-term potentiation of the amygdala-prefrontal cortex pathway in vivo. J. Neurosci. 2003, 23, 4406-4409. [CrossRef]

158. Rosenkranz, J.A.; Venheim, E.R.; Padival, M. Chronic stress causes amygdala hyperexcitability in rodents. Biol. Psychiatry 2010, 67, 1128-1136. [CrossRef]

159. Suvrathan, A.; Bennur, S.; Ghosh, S.; Tomar, A.; Anilkumar, S.; Chattarji, S. Stress enhances fear by forming new synapses with greater capacity for long-term potentiation in the amygdala. Philos. Trans. R. Soc. Lond. B Biol. Sci. 2014, 369, 20130151. [CrossRef]

160. Leuner, B.; Gould, E. Dendritic growth in medial prefrontal cortex and cognitive flexibility are enhanced during the postpartum period. J. Neurosci. 2010, 30, 13499-13503. [CrossRef]

161. Chang, C.H.; Berke, J.D.; Maren, S. Single-unit activity in the medial prefrontal cortex during immediate and delayed extinction of fear in rats. PLoS ONE 2010, 5, e11971. [CrossRef]

162. Kim, S.C.; Jo, Y.S.; Kim, I.H.; Kim, H.; Choi, J.S. Lack of medial prefrontal cortex activation underlies the immediate extinction deficit. J. Neurosci. 2010, 30, 832-837. [CrossRef]

163. Stafford, J.M.; Maughan, D.K.; Ilioi, E.C.; Lattal, K.M. Exposure to a fearful context during periods of memory plasticity impairs extinction via hyperactivation of frontal-amygdalar circuits. Learn Mem. 2013, 20, 156-163. [CrossRef]

164. Judo, C.; Matsumoto, M.; Yamazaki, D.; Hiraide, S.; Yanagawa, Y.; Kimura, S.; Shimamura, K.; Togashi, H. Early stress exposure impairs synaptic potentiation in the rat medial prefrontal cortex underlying contextual fear extinction. Neuroscience 2010, 169, 1705-1714. [CrossRef]

165. Ishikawa, S.; Saito, Y.; Yanagawa, Y.; Otani, S.; Hiraide, S.; Shimamura, K.; Matsumoto, M.; Togashi, H. Early postnatal stress alters extracellular signal-regulated kinase signaling in the corticolimbic system modulating emotional circuitry in adult rats. Eur. J. Neurosci. 2012, 35, 135-145. [CrossRef] [PubMed]

166. Garcia, R.; Spennato, G.; Nilsson-Todd, L.; Moreau, J.L.; Deschaux, O. Hippocampal low-frequency stimulation and chronic mild stress similarly disrupt fear extinction memory in rats. Neurobiol. Learn. Mem. 2008, 89, 560-566. [CrossRef] [PubMed]

167. Elands, J.; Barberis, C.; Jard, S.; Tribollet, E.; Dreifuss, J.J.; Bankowski, K.; Manning, M.; Sawyer, W.H. 125I-labelled d(CH2)5[Tyr(Me)2,Thr4,Tyr-NH2]OVT: A selective oxytocin receptor ligand. Eur. J. Pharmacol. 1988, 147, 197-207. [CrossRef]

168. Tribollet, E.; Charpak, S.; Schmidt, A.; Dubois-Dauphin, M.; Dreifuss, J.J. Appearance and transient expression of oxytocin receptors in fetal, infant, and peripubertal rat brain studied by autoradiography and electrophysiology. J. Neurosci. 1989, 9 , 1764-1773. [CrossRef] [PubMed] 
169. Insel, T.R.; Young, L.J. The neurobiology of attachment. Nat. Rev. Neurosci. 2001, 2, 129-136. [CrossRef] [PubMed]

170. Nakajima, M.; Görlich, A.; Heintz, N. Oxytocin modulates female sociosexual behavior through a specific class of prefrontal cortical interneurons. Cell 2014, 159, 295-305. [CrossRef] [PubMed]

171. Yoshida, M.; Takayanagi, Y.; Inoue, K.; Kimura, T.; Young, L.J.; Onaka, T.; Nishimori, K. Evidence that oxytocin exerts anxiolytic effects via oxytocin receptor expressed in serotonergic neurons in mice. J. Neurosci. 2009, 29, 2259-2271. [CrossRef]

172. Gimpl, G.; Fahrenholz, F. The oxytocin receptor system: Structure, function, and regulation. Physiol. Rev 2001, 81, 629-683. [CrossRef]

173. Smith, C.J.W.; Poehlmann, M.L.; Li, S.; Ratnaseelan, A.M.; Bredewold, R.; Veenema, A.H. Age and sex differences in oxytocin and vasopressin V1a receptor binding densities in the rat brain: Focus on the social decision-making network. Brain Struct. Funct. 2017, 222, 981-1006. [CrossRef] [PubMed]

174. Boccia, M.L.; Petrusz, P.; Suzuki, K.; Marson, L.; Pedersen, C.A. Immunohistochemical localization of oxytocin receptors in human brain. Neuroscience 2013, 253, 155-164. [CrossRef]

175. Bale, T.L.; Davis, A.M.; Auger, A.P.; Dorsa, D.M.; McCarthy, M.M. CNS region-specific oxytocin receptor expression: Importance in regulation of anxiety and sex behavior. J. Neurosci. 2001, 21, 2546-2552. [CrossRef] [PubMed]

176. Missig, G.; Ayers, L.W.; Schulkin, J.; Rosen, J.B. Oxytocin reduces background anxiety in a fear-potentiated startle paradigm. Neuropsychopharmacology 2010, 35, 2607-2616. [CrossRef] [PubMed]

177. Neumann, I.D.; Slattery, D.A. Oxytocin in General Anxiety and Social Fear: A Translational Approach. Biol. Psychiatry 2016, 79, 213-221. [CrossRef] [PubMed]

178. MacDonald, K.; Feifel, D. Oxytocin's role in anxiety: A critical appraisal. Brain Res. 2014, 1580, 22-56. [CrossRef]

179. Janeček, M.; Dabrowska, J. Oxytocin facilitates adaptive fear and attenuates anxiety responses in animal models and human studies-potential interaction with the corticotropin-releasing factor (CRF) system in the bed nucleus of the stria terminalis (BNST). Cell Tissue Res. 2019, 375, 143-172. [CrossRef]

180. Toth, I.; Neumann, I.D.; Slattery, D.A. Central administration of oxytocin receptor ligands affects cued fear extinction in rats and mice in a timepoint-dependent manner. Psychopharmacology 2012, 223, 149-158. [CrossRef]

181. Borland, J.M.; Aiani, L.M.; Norvelle, A.; Grantham, K.N.; O’Laughlin, K.; Terranova, J.I.; Frantz, K.J.; Albers, H.E. Sex-dependent regulation of social reward by oxytocin receptors in the ventral tegmental area. Neuropsychopharmacology 2019, 44, 785-792. [CrossRef]

182. Eskandarian, S.; Vafaei, A.A.; Vaezi, G.H.; Taherian, F.; Kashefi, A.; Rashidy-Pour, A. Effects of systemic administration of oxytocin on contextual fear extinction in a rat model of post-traumatic stress disorder. Basic Clin. Neurosci. 2013, 4, 315-322.

183. Wang, S.C.; Lin, C.C.; Chen, C.C.; Tzeng, N.S.; Liu, Y.P. Effects of Oxytocin on Fear Memory and Neuroinflammation in a Rodent Model of Posttraumatic Stress Disorder. Int. J. Mol Sci. 2018, 19, 3848. [CrossRef]

184. Acheson, D.; Feifel, D.; de Wilde, S.; McKinney, R.; Lohr, J.; Risbrough, V. The effect of intranasal oxytocin treatment on conditioned fear extinction and recall in a healthy human sample. Psychopharmacology 2013, 229, 199-208. [CrossRef]

185. de Oliveira, L.F.; Camboim, C.; Diehl, F.; Consiglio, A.R.; Quillfeldt, J.A. Glucocorticoid-mediated effects of systemic oxytocin upon memory retrieval. Neurobiol. Learn. Mem. 2007, 87, 67-71. [CrossRef] [PubMed]

186. Barrett, D.; Gonzalez-Lima, F. Behavioral effects of metyrapone on Pavlovian extinction. Neurosci. Lett. 2004, 371, 91-96. [CrossRef] [PubMed]

187. Young, W.S.; Li, J.; Wersinger, S.R.; Palkovits, M. The vasopressin $1 \mathrm{~b}$ receptor is prominent in the hippocampal area CA2 where it is unaffected by restraint stress or adrenalectomy. Neuroscience 2006, 143, 1031-1039. [CrossRef] [PubMed]

188. Lahoud, N.; Maroun, M. Oxytocinergic manipulations in corticolimbic circuit differentially affect fear acquisition and extinction. Psychoneuroendocrinology 2013, 38, 2184-2195. [CrossRef]

189. Campbell-Smith, E.J.; Holmes, N.M.; Lingawi, N.W.; Panayi, M.C.; Westbrook, R.F. Oxytocin signaling in basolateral and central amygdala nuclei differentially regulates the acquisition, expression, and extinction of context-conditioned fear in rats. Learn Mem. 2015, 22, 247-257. [CrossRef] [PubMed]

190. Viviani, D.; Charlet, A.; van den Burg, E.; Robinet, C.; Hurni, N.; Abatis, M.; Magara, F.; Stoop, R. Oxytocin selectively gates fear responses through distinct outputs from the central amygdala. Science 2011, 333, 104-107. [CrossRef] [PubMed]

191. Gunduz-Cinar, O.; Brockway, E.T.; Castillo, L.I.; Pollack, G.A.; Erguven, T.; Holmes, A. Selective sub-nucleus effects of intraamygdala oxytocin on fear extinction. Behav. Brain Res. 2020, 393, 112798. [CrossRef]

192. Stamatakis, A.; Manatos, V.; Kalpachidou, T.; Stylianopoulou, F. Exposure to a mildly aversive early life experience leads to prefrontal cortex deficits in the rat. Brain Struct. Funct. 2016, 221, 4141-4157. [CrossRef]

193. Burkett, J.P.; Andari, E.; Johnson, Z.V.; Curry, D.C.; de Waal, F.B.; Young, L.J. Oxytocin-dependent consolation behavior in rodents. Science 2016, 351, 375-378. [CrossRef] [PubMed]

194. Hicks, C.; Jorgensen, W.; Brown, C.; Fardell, J.; Koehbach, J.; Gruber, C.W.; Kassiou, M.; Hunt, G.E.; McGregor, I.S. The nonpeptide oxytocin receptor agonist WAY 267,464: Receptor-binding profile, prosocial effects and distribution of c-Fos expression in adolescent rats. J. Neuroendocrinol. 2012, 24, 1012-1029. [CrossRef] [PubMed]

195. Jurek, B.; Neumann, I.D. The Oxytocin Receptor: From Intracellular Signaling to Behavior. Physiol. Rev. 2018, 98, 1805-1908. [CrossRef]

196. Amir, A.; Amano, T.; Pare, D. Physiological identification and infralimbic responsiveness of rat intercalated amygdala neurons. J. Neurophysiol. 2011, 105, 3054-3066. [CrossRef] [PubMed] 
197. Whittle, N.; Hauschild, M.; Lubec, G.; Holmes, A.; Singewald, N. Rescue of impaired fear extinction and normalization of cortico-amygdala circuit dysfunction in a genetic mouse model by dietary zinc restriction. J. Neurosci. 2010, 30, 13586-13596. [CrossRef] [PubMed]

198. Camp, M.C.; Macpherson, K.P.; Lederle, L.; Graybeal, C.; Gaburro, S.; Debrouse, L.M.; Ihne, J.L.; Bravo, J.A.; O'Connor, R.M.; Ciocchi, S.; et al. Genetic strain differences in learned fear inhibition associated with variation in neuroendocrine, autonomic, and amygdala dendritic phenotypes. Neuropsychopharmacology 2012, 37, 1534-1547. [CrossRef]

199. Singewald, N.; Holmes, A. Rodent models of impaired fear extinction. Psychopharmacology 2019, 236, 21-32. [CrossRef] [PubMed]

200. Brill-Maoz, N.; Maroun, M. Extinction of fear is facilitated by social presence: Synergism with prefrontal oxytocin. Psychoneuroendocrinology 2016, 66, 75-81. [CrossRef]

201. Kritman, M.; Lahoud, N.; Maroun, M. Oxytocin in the amygdala and not the prefrontal cortex enhances fear and impairs extinction in the juvenile rat. Neurobiol. Learn. Mem. 2017, 141, 179-188. [CrossRef] [PubMed]

202. Herry, C.; Ferraguti, F.; Singewald, N.; Letzkus, J.J.; Ehrlich, I.; Lüthi, A. Neuronal circuits of fear extinction. Eur. J. Neurosci. 2010, 31, 599-612. [CrossRef] [PubMed]

203. Burgos-Robles, A.; Vidal-Gonzalez, I.; Santini, E.; Quirk, G.J. Consolidation of fear extinction requires NMDA receptor-dependent bursting in the ventromedial prefrontal cortex. Neuron 2007, 53, 871-880. [CrossRef]

204. Herry, C.; Garcia, R. Prefrontal cortex long-term potentiation, but not long-term depression, is associated with the maintenance of extinction of learned fear in mice. J. Neurosci. 2002, 22, 577-583. [CrossRef]

205. Vouimba, R.M.; Maroun, M. Learning-induced changes in mPFC-BLA connections after fear conditioning, extinction, and reinstatement of fear. Neuropsychopharmacology 2011, 36, 2276-2285. [CrossRef] [PubMed]

206. Maroun, M.; Kavushansky, A.; Holmes, A.; Wellman, C.; Motanis, H. Enhanced extinction of aversive memories by high-frequency stimulation of the rat infralimbic cortex. PLoS ONE 2012, 7, e35853. [CrossRef] [PubMed]

207. Ninan, I. Oxytocin suppresses basal glutamatergic transmission but facilitates activity-dependent synaptic potentiation in the medial prefrontal cortex. J. Neurochem. 2011, 119, 324-331. [CrossRef]

208. Nuss, P. Anxiety disorders and GABA neurotransmission: A disturbance of modulation. Neuropsychiatr. Dis. Treat. 2015, 11, 165-175.

209. Smith, A.S.; Tabbaa, M.; Lei, K.; Eastham, P.; Butler, M.J.; Linton, L.; Altshuler, R.; Liu, Y.; Wang, Z. Local oxytocin tempers anxiety by activating GABAA receptors in the hypothalamic paraventricular nucleus. Psychoneuroendocrinology 2016, 63, 50-58. [CrossRef]

210. Mody, I.; Pearce, R.A. Diversity of inhibitory neurotransmission through GABA(A) receptors. Trends Neurosci. 2004, 27, 569-575. [CrossRef]

211. Farrant, M.; Nusser, Z. Variations on an inhibitory theme: Phasic and tonic activation of GABA(A) receptors. Nat. Rev. Neurosci. 2005, 6, 215-229. [CrossRef] [PubMed]

212. Bowery, N.G. Historical perspective and emergence of the GABAB receptor. Adv. Pharmacol. 2010, 58, 1-18. [PubMed]

213. Bowen, M.T.; Peters, S.T.; Absalom, N.; Chebib, M.; Neumann, I.D.; McGregor, I.S. Oxytocin prevents ethanol actions at $\delta$ subunit-containing GABAA receptors and attenuates ethanol-induced motor impairment in rats. Proc. Natl. Acad. Sci. USA 2015, 112, 3104-3109. [CrossRef] [PubMed]

214. Qi, J.; Han, W.Y.; Yang, J.Y.; Wang, L.H.; Dong, Y.X.; Wang, F.; Song, M.; Wu, C.F. Oxytocin regulates changes of extracellular glutamate and GABA levels induced by methamphetamine in the mouse brain. Addict. Biol. 2012, 17, 758-769. [CrossRef] [PubMed]

215. Sabihi, S.; Dong, S.M.; Maurer, S.D.; Post, C.; Leuner, B. Oxytocin in the medial prefrontal cortex attenuates anxiety: Anatomical and receptor specificity and mechanism of action. Neuropharmacology 2017, 125, 1-12. [CrossRef]

216. Farb, D.H.; Ratner, M.H. Targeting the modulation of neural circuitry for the treatment of anxiety disorders. Pharmacol. Rev. 2014, 66, 1002-1032. [CrossRef]

217. Viviani, D.; Terrettaz, T.; Magara, F.; Stoop, R. Oxytocin enhances the inhibitory effects of diazepam. in the rat central medial amygdala. Neuropharmacology 2010, 58, 62-68. [CrossRef]

218. Kreuder, A.K.; Scheele, D.; Schultz, J.; Hennig, J.; Marsh, N.; Dellert, T.; Ettinger, U.; Philipsen, A.; Babasiz, M.; Herscheid, A.; et al. Common and dissociable effects of oxytocin and lorazepam. on the neurocircuitry of fear. Proc. Natl. Acad. Sci. USA 2020, 117, 11781-11787. [CrossRef]

219. Hu, J.; Wang, Z.; Feng, X.; Long, C.; Schiller, D. Post-retrieval oxytocin facilitates next day extinction of threat memory in humans. Psychopharmacology 2019, 236, 293-301. [CrossRef]

220. Guastella, A.J.; Howard, A.L.; Dadds, M.R.; Mitchell, P.; Carson, D.S. A randomized controlled trial of intranasal oxytocin as an adjunct to exposure therapy for social anxiety disorder. Psychoneuroendocrinology 2009, 34, 917-923. [CrossRef]

221. Guastella, A.J.; Graustella, A.J.; MacLeod, C. A critical review of the influence of oxytocin nasal spray on social cognition in humans: Evidence and future directions. Horm Behav. 2012, 61, 410-418. [CrossRef] [PubMed] 